\title{
40. PROBABILISTIC ZONATION OF EARLY CRETACEOUS MICROFOSSIL SEQUENCES, ATLANTIC AND INDIAN OCEANS, WITH SPECIAL REFERENCE TO LEG $123^{1}$
}

\author{
Felix M. Gradstein, ${ }^{2,3}$ Zehui Huang, ${ }^{3}$ Doug Merrett, ${ }^{3}$ and James G. Ogg ${ }^{4}$
}

\begin{abstract}
A database was built of 378 stratigraphic events, including first and last stratigraphic occurrences (FO/LO) of calcareous nannofossils, foraminifers, and dinocysts, and geomagnetic reversal occurrences in Latest Jurassic through Early Cretaceous deep-marine strata of 10 Atlantic and three Indian Ocean drilling sites. A total 136 different events are included, about one-third of which are unique to either ocean; however, this number may decrease when more Indian Ocean ODP sites become available for study. Using the complete data set, with the quantitative stratigraphy methods STRATCOR and RASC, we calculated closely comparable optimum sequences of average first and last occurrence positions. The preferred zonal solution, based on the STRATCOR method, includes 56 events, each of which occurs in 3 or more sites and comprises 6 geomagnetic reversal events, 25 nannofossils, 5 planktonic and 8 benthic foraminifers, and 12 dinocysts. Eight assemblage zones of Tithonian through Albian age have been recognized that correlate most of these sites. The nannofossil events, Cruciellipsis cuvillieri FO, Tubodiscus verenae FO, Rucinolithus wisei LO, and Chiastozygus litterarius FO, in the Atlantic Ocean are half a stage or more older than those in the Indian Ocean. Stratigraphic ranges of the benthic foraminifers Haplophragmium inconstans. Trochammina quinqueloba, and Dorothia praehauteriviana, differ significantly among sites. The same is true for the dinocyst events Phoberocysta neocomica LO and Druggidium apicopaucicum LO, rendering these taxa less useful for zonation and correlation.
\end{abstract}

\section{INTRODUCTION}

We propose a quantitative zonation using nannofossil, foraminifer, dinocyst, and geomagnetic reversal events in Uppermost Jurassic and Lower Cretaceous sediments in 10 Atlantic and 3 Indian Ocean sites. Indian Ocean sites are from DSDP Leg 27 and from ODP Leg 123, which had as one objective the study of Mesozoic biostratigraphy and biochronology in relation to the Atlantic oceanic record.

Conventional biostratigraphy generally lacks direct integration between individual microfossil disciplines before building a multiple zonation and rarely gives insight in the actual geographic distributions of taxa and zones. To a great extent, this is a result of the considerable regional diversity of the microfossil record, the degree of specialization needed to "digest" data from any one microfossil group, such as coccolithophorids, benthic foraminifers, and dinocysts, and the lack of standardized recording and retrieval procedures in stratigraphic paleontology. In addition, conventional qualitative methods are poorly suited for integrating records prior to zonation. For the ultimate in conventional stratigraphic resolution, considerable emphasis is placed on the end-points of (micro) fossil ranges in key sections. Unfortunately, few sites provide consistent order and presence of all "zonal" or "index" taxa proposed, which leads to considerable subjective judgment on the part of individual scientists regarding zonation, based on the perceived "true" order of taxa.

Modern quantitative zonation and correlation techniques provide a means for calculating average or total stratigraphic ranges for a variety of fossil taxa in one integrated and more objective

\footnotetext{
${ }^{1}$ Gradstein, F. M., Ludden, J. N., et al., 1992. Proc. ODP, Sci. Results, 123 College Station, TX (Ocean Drilling Program).

2 Atlantic Geoscience Centre, Bedford Institute of Oceanography, Dartmouth, Nova Scotia B2Y 4A2, Canada.

${ }^{3}$ Department of Geology, Dalhousie University, Halifax, Nova Scotia B3H 3J5, Canada.

${ }^{4}$ Department of Earth and Atmospheric Sciences, Purdue University, West Lafayette, IN 47907 , U.S.A.
}

zonation. If average ranges are one's objective, then the procedure treats local inconsistencies in relative position of the end-points of ranges (first and last occurrence events) as local, random deviations from estimated average event locations. Using error bars, uncertainty may be exposed in the total stratigraphic ranges of taxa. Estimates of errors emphasize the probabilistic, rather than deterministic, nature of stratigraphic solutions. In this manner, debate about a so-called "true" zonation is circumvented. If total stratigraphic ranges are one's objective, as with qualitative, deterministic biostratigraphic methodology, then stratigraphic inconsistencies are assumed to result from missing data and are eliminated by filling in the data gaps, until a consistent database is obtained. Probabilistic techniques can be used to calculate usable zonations in noisy data sets that contain many sites and are suitable for groups of fossils, where a large deviation occurs between local and average stratigraphic ranges, as with many benthic organisms.

Quantitative techniques allow one to calculate integrated zonations and their correlations quickly and easily, once the data have been standardized. The process is iterative between interim answers and data, such that taxonomic bias, stratigraphic outliers, and absence of stratigraphic and taxonomic communality among sites may be quickly identified. Next, corrective measures may be taken to optimize zonations using "filtered" data, much like stepwise filtering of geophysical data during processing.

The richness of stratigraphic data in DSDP and ODP holes varies with location, determined by depositional conditions and the degree of diagenetic alteration. Studies of these data have given insight into Jurassic and Early Cretaceous stratigraphy, but most previous stratigraphic research was performed either independently on the basis of a certain fossil group among several holes (Habib, 1977, 1982) or on the basis of several fossil groups in one or two drilling sites in the form of a stratigraphic summary of a drilling leg. Jansa et al. (1979) and Ogg (1987) were the first to use various groups of fossils (nannofossils, dinoflagellates, and ammonites) and geomagnetic polarity to correlate holes (e.g., DSDP Holes 534A and 603B). Gradstein (1986) synthesized empirically Mesozoic biozonations of various fossil groups in the northwestern Atlantic Ocean. 
For a more comprehensive understanding of deep-water Mesozoic biostratigraphy, one must draw on as much information from various stratigraphic disciplines (foraminifers, nannofossils, dinoflagellates, geomagnetic polarity) as possible, preferably in a quantitative way. The stratigraphy developed on the basis of a certain fossil group in a single hole or a small area almost always suffers from redeposition and diagenetic alteration (dissolution), and sometimes misidentification. This stratigraphy may not be complete and representative enough because of diachroneity of some species.

Here, we use quantitative methods to process stratigraphic data (foraminifers, nannofossils, dinoflagellates, geomagnetic polarity) collected from 10 DSDP holes in the Atlantic Ocean (Fig. 1). We compare the Atlantic optimum stratigraphic record to that from two recently completed sites during Leg 123 in the Indian Ocean (Fig. 2) and a nearby DSDP Leg 27 site, to assess direct correlation among sites. The ODP database of 13 sites contains both pelagic and benthic fossils and has "missing" data, the reason why a probabilistic approach was preferred. Further study will be warranted to refine these zonations, using a deterministic pathway in the methods presented.

In the quantitative approach, two methods are used to calculate optimum biozonations. The first method is based on the F77 program STRATCOR, which is a crossplotting method for analyzing hole or outcrop data in succession, so as to build a composite sequence of events. The second method is the F77 program RASC, which uses matrix permutation on frequency of event occurrences to subject all data simultaneously to biostratigraphic sequence analysis. Both methods are summarized here. One of the results from STRATCOR is referred to as the Final Composite Standard Sequence (FCSS), which is expressed either as a listing or as a dendrogram of interevent distances in relative time. Both methods present more direct and more objective insights in the stratigraphic use of different fossil groups and geomagnetic reversal events than conventionally constructed zonations.

\section{METHODS}

Graphic correlation, also called Shaw's method, was proposed by Shaw (1964) and has become accepted and used by stratigraphers since that time as a semi-objective tool to assess the fossil record for purposes of zonation and correlation. This is actually a type of "crossplotting" method, where one compares order with spacing of stratigraphic events in pairs of sections, using $x-y$ scatter plots. In this comparison, one section is considered the reference, while other sections are used one by one for updating data of the reference section to produce a composite sequence. The line of correlation (LOC) is derived either from subjectively connecting events in two-way scattergrams, or from a statistically modeled line of the scattered points. Traditionally, stratigraphers have used either single straight lines or segmented straight lines as LOCs. Miller (1977) and Edwards (1989) gave good accounts of the history and use of this relatively simple, but stratigraphically useful and consistently popular, method.

For more efficient use of graphic correlation, this method has now been extensively modified and computerized for use with personal computers having graphics cards and a mathematical co-processor. This F77 program, named STRATCOR (version 2.0; Gradstein, 1990), performs both biozonation and correlation of fossil events in sedimentary strata. Examples of fossil events are the first or last occurrences of taxa in samples from holes or outcrop sections (i.e., the local stratigraphic range end-points). This method allows one to calculate a zonation, even if some events in the database occur in only a few sequences. In comparison with another quantitative technique, RASC (see below), whose results rely more on the occurrence frequency of the events in the database, STRATCOR is a more suitable tool for dealing with our smaller and more patchy data (see "Data," section, this chapter).

The program STRATCOR executes in two stages. During Stage 1, all hole sequences are incorporated in succession to form a Final Composite Standard Sequence (FCSS). During Stage 2, the FCSS is correlated with individual holes.

In detail, the method proceeds as follows: first, events in an assigned reference hole (number 1 for the program and the dependent variable) are expressed as a function of the events in common with hole number 2 (the independent variable). During Stage 1, only order of events is used in the event (hole) sequences, not their depths in feet or meters. Thus, event sequences have no scale, only an order. A best-fit line is constructed for the scattergram of events in common using cubic spline fitting. Thus, the LOC built into this program is a curved, smooth line. The program automatically calculates three smoothed spline fits:

1. A minimally smoothed fit, such that deviation to all points is minimized, but such that the curve remains monotonic (i.e., always shows positive increases in both $x$ and $y$ directions and does not return on itself, which creates a geologically impossible negative sedimentation rate).

2. Maximum smoothing, which is a linear regression line.

3. The average of the two previous cubic spline fits.

In addition, the user may select his own smoothing factor, as long as it is monotonic; user-controlled weights on event positions may "steer" the fit, such that it is stratigraphically most satisfac-

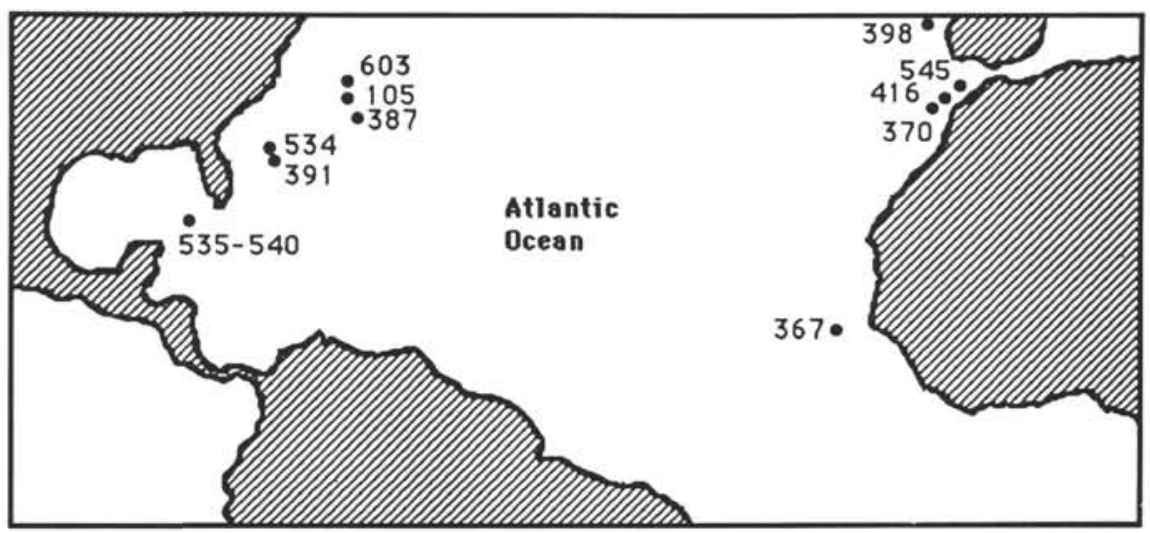

Figure 1. Location of 10 Atlantic Ocean sites that were cored during DSDP Legs 11, 41, 43, 44 , $48 \mathrm{~A}, 50,76,77$, and 93. 


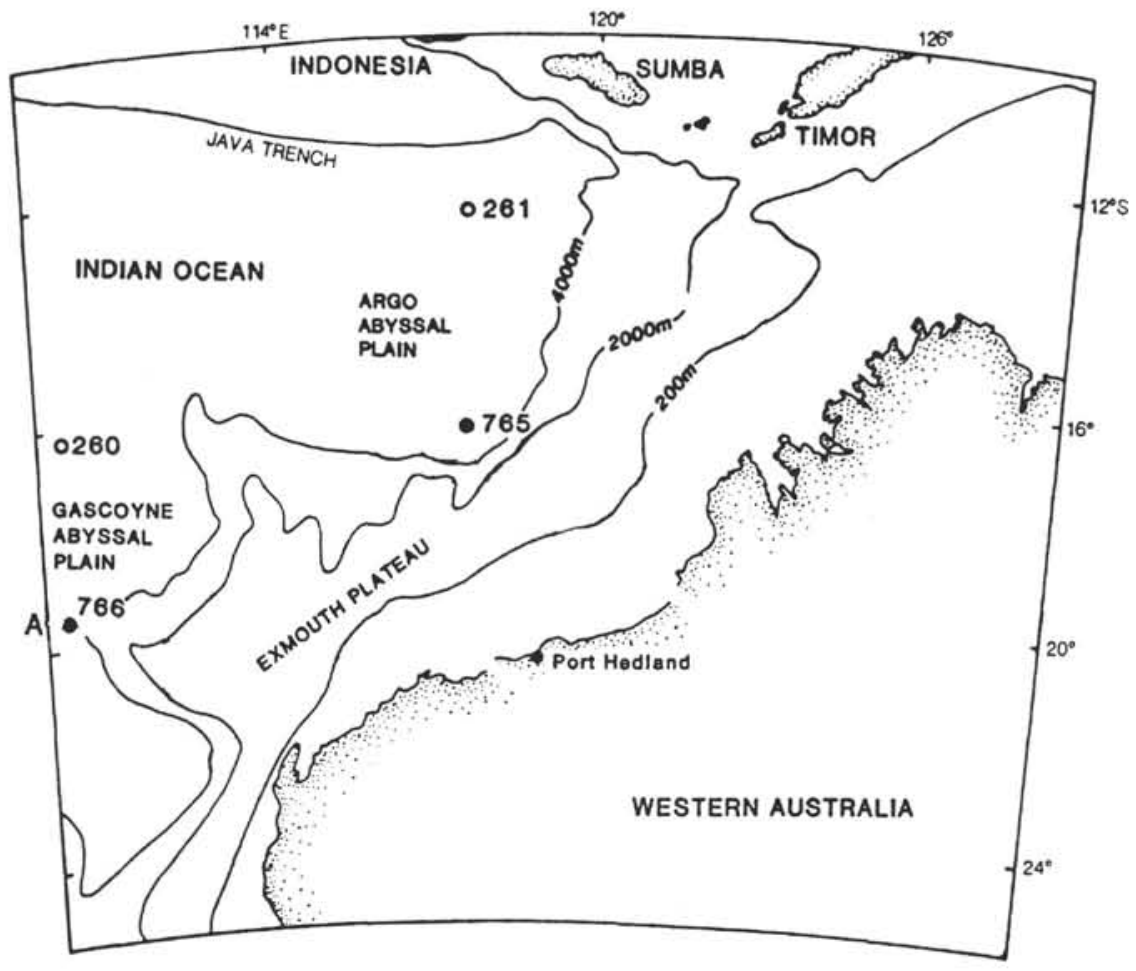

Figure 2. Location of three Indian Ocean sites that were cored during DSDP Leg 27 and ODP Leg 123.

tory and, for example, models a hiatus in a hole. In general, minimum smoothing is the preferred option, because the LOC stays nearest the observed data points, and two-way deviations from the LOC to the data points are minimized.

Events not previously in the reference hole are added at their interpolated positions. When an event in the reference hole also occurs in the individual hole, it has an interpolated position in the reference section. At this stage, the user may select one of the following stratigraphic rules to calculate the newly interpolated position in the reference hole (interim composite standard). The new position may be (1) the highest, (2) the lowest, (3) the unweighted average, or (4) the weighted average of the previous and interpolated positions in the reference hole (Fig. 3). The first two interpolation methods, Methods 1 and 2, lead to deterministic zonations, Methods 3 and 4 create probabilistic ones.

Following the interpolation of Hole 2 in Hole 1, the order of the individual record in Hole 3 is crossplotted with the previous composite, upon which interpolation again updates this composite record, and so on. The final composite standard sequence (FCSS) uses the individual stratigraphic record in all holes or outcrop sections. Stage 1 can be repeated up to 99 times, if necessary, for stabilizing the FCSS. Note that the first and last occurrence events in the FCSS are spaced along a relative stratigraphic scale that is a composite of all order relationships in all holes examined.

During Stage 2, the correlation stage of STRATCOR, the FCSS again is crossplotted with the fossil record in each individual hole, now expressed in the original depth units of measurements. Again, the composite is expressed as a function of the individual record, using cubic smoothing splines, but now the composite is interpolated in each hole to find the local depth of each composite event. The resulting correlation framework serves to draw detailed cross sections among holes or outcrop sections.

Program STRATCOR consists of three interactive modules: PREP.EXE, GRACOR.EXE, and DENDRO.EXE. The first module is a pre-processor of input data, which conform to the so-called RASC/CASC format (see below; i.e., event dictionary file, event- sequence file, and event-depth file). PREP converts the RASC/ CASC-type input data to the input format of GRACOR. More importantly, it permits the user (1) to set a threshold for minimum event occurrence, (2) to include rare events, and (3) to determine the order in which the holes or outcrop sections are processed interactively in GRACOR. GRACOR is the main program; it calculates a probabilistic or deterministic biozonation, depending on the choice of interpolation rule, and correlates the zonation through the holes. Program DENDRO displays the FCSS in dendrogram format to visualize interval or assemblage zones.

Program STRATCOR works well with both small and patchy data files that 3 to 10 holes, or with files based on dozens of holes and hundreds of taxa. In contrast, program RASC (Ranking and Scaling), developed by F. P. Agterberg and F. M. Gradstein (Gradstein et al., 1985; Agterberg et al., 1989; Agterberg, 1990), handles all event data simultaneously in large matrixes that are subject to permutations to organize the event data in an optimum sequence. The RASC method both ranks and scales biostratigraphic events in relative time. We did not attempt scaling as it generally requires larger data files and appears more suitable for benthic organisms having some inconsistencies in event order among holes than for (calcareous) planktonic organisms that form relatively consistent order in relative time among sites. The ranking method can be used with only 10 holes, if reasonable overlap in stratigraphic sequences exists, as is the case here. The result of ranking is a so-called Optimum Sequence that provides insight about the most likely order of the stratigraphic first and last occurrence events. As we will see, the FCSS from STRATCOR and the Optimum Sequence based on RASC show excellent stratigraphic convergence, which confirms the stratigraphic value of the zonal solutions.

\section{DATA}

Data for this investigation are from 10 DSDP sites in the Atlantic Ocean and 1 DSDP site and 2 ODP sites in the eastern Indian Ocean (Figs. 1, 2). All sites, except Site 387, Hole 398D, 


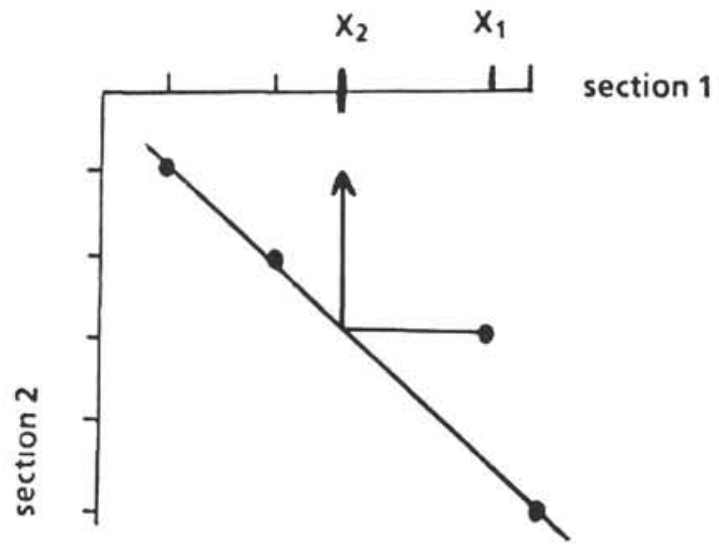

highest position
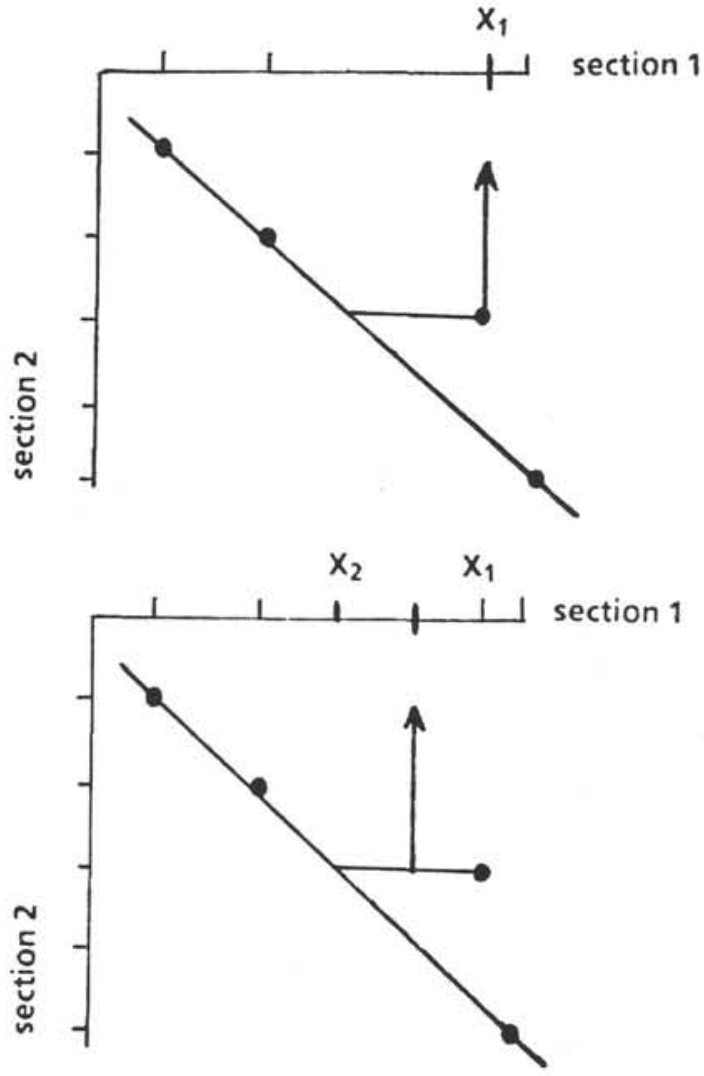

$$
y=x_{2}
$$

lowest position

$$
y=X_{1}
$$

average position

$$
y=\frac{x_{1}+x_{2}}{2}
$$

weighted average position

$$
y=\frac{N \cdot X_{1}+X_{2}}{N+1}
$$

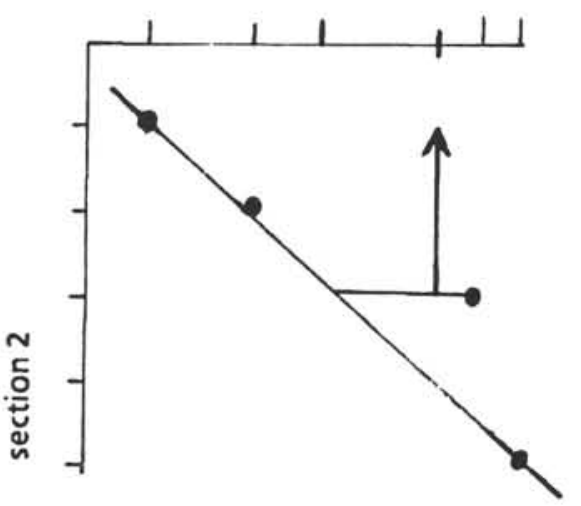

Figure 3. Four methods of stratigraphic interpolation, using smoothing cubic spline fitting in the crossplot method STRATCOR for biozonation and correlation. 
and Site 766 , bottomed in Jurassic oceanic basement and were already below a water depth of $4 \mathrm{~km}$ during the Early Cretaceous. Site 387 and Hole 398D originated in Earliest Cretaceous time and were in a paleowater depth of between 2.7 and $4 \mathrm{~km}$ (Jansa et al., 1979). Site 766, located on volcanic sills of Chron M11 age at the northwestern Australian ocean/continent boundary, was less than $1500 \mathrm{~m}$ deep during Early Cretaceous time (Ludden, Gradstein, et al., 1990).

The stratigraphic events included in this study are the first occurrence (FO) and/or last occurrence (LO) of important planktonic (PF) and benthic (BF) foraminifers, nannofossils (N) and dinoflagellates $(\mathrm{P})$, which are often observed and commonly considered for stratigraphy of individual holes, and geomagnetic reversal events (M). We did not include rare fossil groups, such as ammonites and ostracods, and also excluded radiolarians and calpionellids because of an absence of systematic data among all sites examined. Once such data are available, it should be an easy matter to add and recalculate the zonations and correlations.

The data were collected mainly from research papers in relevant DSDP and ODP Initial Reports volumes and in other publications. The quantity and quality of stratigraphic data vary from hole to hole for various reasons. Apart from geological factors, such as depositional conditions and diagenetic process, coring interval, core recovery, and sampling density are the major factors determining the quantity and quality of the data from these holes. Detailed geomagnetic polarity study is limited to DSDP Holes 534A and 603B (Ogg, 1983, 1987). Important foraminifers (planktonic and benthic) are sparse in most of these holes, mainly because of dissolution and difficulties when separating the fossils from the calcareous host rock. Calcareous nannofossil data are more abundant and dominate our database. Systematic studies about dinoflagellates were conducted for DSDP Holes 105, 387, 391, 534A and 603B (Habib, 1972, 1978, 1979; Habib and Drugg, 1983, 1987). More stratigraphically useful data can be found in the western Atlantic Ocean than in the eastern Atlantic or Indian oceans.

The form of data presentation in the examined published research papers varies from tabulated fossil examination results to species range charts and to simply narratives in the text. The most favorable form of data presentation for our data acquisition is the tabulated fossil examination results per sample, which allow us to recognize and avoid abnormally high fossil occurrence (first or last), because of turbiditic deposits, as is the case in DSDP Holes $603 \mathrm{~B}$ and $534 \mathrm{~A}$, or because of poor preservation. Fossil range charts are subject to interpretation of the researcher. Narratives about fossil occurrences in a text are more likely to introduce noise into our database. The source of our data is listed in Table 1; a so-called event dictionary, which lists the unique code number of all taxa and magnetic polarity events, appears in Appendix $\mathrm{A}$, and a complete paleontological text file that lists all data used is presented in Appendix B. The sequence of the holes arranged in the master data file of Appendix B is in accordance with the abundance and quality of the data per ocean. DSDP Hole 534A has been ranked as the primary hole (reference site), not only

Table 1. Source of data used for this study.

\begin{tabular}{|c|c|c|c|c|}
\hline Hole & Foraminifers & Nannofossils & Dinoflagellates & $\begin{array}{c}\text { Magnetic } \\
\text { event }\end{array}$ \\
\hline 105 & Luterbacher (1972) & $\begin{array}{l}\text { Wilcoxon } \\
\qquad(1972)\end{array}$ & $\begin{array}{l}\text { Habib (1972) } \\
\text { Habib (1977) } \\
\text { Habib (1977) }\end{array}$ & \\
\hline $\begin{array}{l}367 \\
+ \\
370\end{array}$ & $\begin{array}{l}\text { Kuznetsova and Seibold } \\
\text { (1978) } \\
\text { Pflaumann and } \\
\text { Krashenninikov (1978) } \\
\text { Gradstein (1978a) }\end{array}$ & Cepek (1978) & Williams (1978) & \\
\hline 387 & McNulty (1979) & $\begin{array}{c}\text { Okada et al. } \\
\text { (1979) }\end{array}$ & $\begin{array}{l}\text { Habib (1977) } \\
\text { Habib (1979) }\end{array}$ & \\
\hline $391 \mathrm{C}$ & Gradstein (1978b) & $\begin{array}{l}\text { Schmidt (1978) } \\
\text { Roth (1978) }\end{array}$ & $\begin{array}{l}\text { Habib (1978) } \\
\text { Habib and Knapp } \\
\quad(1982)\end{array}$ & \\
\hline 398D & Sigal (1979) & $\begin{array}{c}\text { Blechschmidt } \\
\text { (1979) }\end{array}$ & & \\
\hline $416 \mathrm{~A}$ & Sliter (1980) & $\begin{array}{c}\text { Cepek et al. } \\
(1980)\end{array}$ & & \\
\hline $534 \mathrm{~A}$ & Gradstein (1983) & Roth (1983) & Habib et al. (1983) & Ogg (1983) \\
\hline $\begin{array}{l}535 \mathrm{~A} \\
+ \\
540\end{array}$ & $\begin{array}{l}\text { Silva and McNulty } \\
(1984) \\
\text { Sliter and Silva } \\
(1984)\end{array}$ & $\begin{array}{l}\text { Watkins and } \\
\text { Bowdler } \\
(1984)\end{array}$ & $\begin{array}{l}\text { Riley and Fenton } \\
\qquad(1984)\end{array}$ & \\
\hline 545 & Leckie (1984) & $\begin{array}{l}\text { Wiegang } \\
\text { (1984) }\end{array}$ & & \\
\hline $603 \mathrm{~B}$ & & $\begin{array}{l}\text { Covington et al. } \\
\qquad(1987)\end{array}$ & $\begin{array}{c}\text { Habib et al. } \\
\text { (1987) }\end{array}$ & Ogg (1987) \\
\hline $\begin{array}{l}765 \mathrm{C} \\
+ \\
766 \mathrm{~A} \\
+ \\
261\end{array}$ & $\begin{array}{l}\text { Kaminski et al. } \\
\text { (this vol.) }\end{array}$ & $\begin{array}{l}\text { Mutterlose } \\
\text { (this vol.) }\end{array}$ & $\begin{array}{l}\text { Helby and } \\
\text { McMinn } \\
\text { (this vol.) }\end{array}$ & $\begin{array}{l}\text { Ogg } \\
\text { (in press) }\end{array}$ \\
\hline
\end{tabular}


because it had more events, but also because it covered a longer geological time period.

A special problem was created when in several sites first and last occurrences of four taxa were anomalously close together. In Site 534, this involved Dorothia praehauteriviana FO and LO (BF) at 1167 and 1149 mbsf, respectively, and Lenticulina nodosa FO and LO (BF) at 1167 and 1149 mbsf, respectively. In Site 370, $L$. nodosa $\mathrm{LO}(\mathrm{BF})$ was recorded only one sample above $L$. nodosa FO, and the same was true for L. barremiana FO and LO (BF) in Site 766, and for Tubodiscus verenae FO and LO (N) in Site 261. Because this involved mostly benthic foraminifers suggests either (1) that the environment was favorable for their local existence for a short time only or (2) that dissolution was important part of destroying the stratigraphic range. During trial runs to calculate and compare both STRATCOR FCSS and RASC Optimum Sequence with and without this record, solutions converged most with the record of $L$. nodosa LO and D. praehauteriviana LO deleted altogether, and this practice was adopted. In addition, crossplots with the FCSS showed that $L$. barremiana LO in Site 766 at 275 mbsf, and $T$. verenae LO in Site 261 at 449 mbsf were outliers. Hence, this relatively unimportant information also was omitted. Should further studies indicate that such outliers are indicative of diachroneity, their use may be reinstated.

\section{ZONAL COMPUTATION}

Zonal computations proceeded in three steps. First, we calculated an FCSS, using the data of all 13 holes. Next, we compared the FCSS with the Optimum Sequence using RASC to assess method-dependent trends. Third, we compared the FCSS in 10 Atlantic holes with that in 3 Indian Ocean sites to emphasize interoceanic differences in zonation. Finally, we propose a "universal" zonation, which may be used easily for geological correlation.

Before zonal calculations, one should gain insight in the frequency distribution of the events. This exercise takes the form of inspection of several tables. The first one (Table 2) shows DSDP and ODP holes as listed in our data file (Appendix B), numbered from 1 through 13, with the number of samples (depths) per site, which varies from 13 to 56 , and the number of event occurrences per site, which varies from 17 to 62 . Useful information for determining which events meet or do not meet selected thresholds is given in Table 3, which shows the ciictionary events and the

Table 2. Holes with number of samples (depths) and number of stratigraphic events per site.

\begin{tabular}{cccc}
\hline \multirow{2}{*}{$\begin{array}{c}\text { Hole } \\
\text { number }\end{array}$} & \multicolumn{2}{c}{ Number of } & \\
\cline { 2 - 3 } & depths & occurrences & Hole name \\
\hline 1 & 56 & 62 & $534 \mathrm{~A}$ \\
2 & 45 & 46 & $603 \mathrm{~B}$ \\
3 & 29 & 34 & $391 \mathrm{C}$ \\
4 & 20 & 20 & 105 \\
5 & 19 & 27 & 370 \\
6 & 20 & 20 & $535 \mathrm{~A}$ \\
7 & 26 & 28 & $416 \mathrm{~A}$ \\
8 & 17 & 17 & $398 \mathrm{D}$ \\
9 & 13 & 18 & 367 \\
10 & 15 & 17 & 387 \\
11 & 34 & 51 & 765 \\
12 & 15 & 20 & 766 \\
13 & 13 & 18 & 261
\end{tabular}

Number of holes: 13 Number of occurrences: 378

Note: these holes were processed in the order $1,3,2$, $4,5,6,7,8,9,10,11,13,12$, which maximizes the number of taxa in common among individual sites.
Table 3. Dictionary events and number of holes in which they occur.

\begin{tabular}{|c|c|c|c|c|c|}
\hline $\begin{array}{c}\text { Event } \\
\text { number }\end{array}$ & $\begin{array}{l}\text { Number } \\
\text { of holes }\end{array}$ & $\begin{array}{c}\text { Event } \\
\text { number }\end{array}$ & $\begin{array}{l}\text { Number } \\
\text { of holes }\end{array}$ & $\begin{array}{c}\text { Event } \\
\text { number }\end{array}$ & $\begin{array}{l}\text { Number } \\
\text { of holes }\end{array}$ \\
\hline 1 & 1 & 101 & 1 & 221 & 1 \\
\hline 2 & 2 & 154 & 8 & 251 & 5 \\
\hline 7 & 8 & 155 & 13 & 253 & 6 \\
\hline 8 & 5 & 156 & 4 & 254 & 3 \\
\hline 10 & 2 & 157 & 7 & 255 & 5 \\
\hline 12 & 2 & 158 & 2 & 256 & 5 \\
\hline 13 & 2 & 159 & 6 & 257 & 6 \\
\hline 18 & 1 & 160 & 6 & 259 & 8 \\
\hline 19 & 1 & 163 & 4 & 261 & 4 \\
\hline 20 & 4 & 164 & 1 & 262 & 3 \\
\hline 21 & 1 & 165 & 5 & 263 & 3 \\
\hline 22 & 1 & 171 & 4 & 264 & 3 \\
\hline 24 & 4 & 173 & 4 & 266 & 4 \\
\hline 26 & 1 & 176 & 5 & 267 & 1 \\
\hline 27 & I & 180 & 1 & 268 & 1 \\
\hline 29 & 1 & 184 & 5 & 269 & 1 \\
\hline 32 & 1 & 185 & 7 & 270 & 1 \\
\hline 36 & 3 & 186 & 3 & 271 & 1 \\
\hline 37 & 1 & 187 & 3 & 272 & 1 \\
\hline 40 & 2 & 188 & 10 & 273 & 1 \\
\hline 41 & 2 & 189 & 7 & 274 & 1 \\
\hline 55 & 7 & 190 & 4 & 275 & 1 \\
\hline 56 & 1 & 191 & 1 & 276 & 1 \\
\hline 57 & 1 & 193 & 3 & 301 & 2 \\
\hline 60 & 3 & 194 & 2 & 303 & 2 \\
\hline 67 & 3 & 195 & 5 & 304 & 2 \\
\hline 68 & 3 & 196 & 4 & 305 & 2 \\
\hline 70 & 1 & 197 & 2 & 307 & 3 \\
\hline 71 & 4 & 200 & 2 & 309 & 4 \\
\hline 72 & 1 & 202 & 2 & 311 & 2 \\
\hline 74 & 5 & 203 & 4 & 315 & 2 \\
\hline 76 & 3 & 204 & 5 & 316 & 2 \\
\hline 78 & 2 & 206 & 4 & 317 & 3 \\
\hline 87 & 2 & 208 & 3 & 318 & 2 \\
\hline 88 & 4 & 209 & 2 & 319 & 1 \\
\hline 89 & 2 & 210 & 2 & 321 & 3 \\
\hline 90 & 2 & 211 & 2 & 322 & 2 \\
\hline 91 & 1 & 212 & 2 & 323 & 3 \\
\hline 92 & 1 & 213 & 2 & 324 & 2 \\
\hline 93 & 1 & 214 & 2 & 325 & 3 \\
\hline 94 & 1 & 215 & 1 & 338 & 2 \\
\hline 95 & 1 & 216 & $i$ & 339 & 2 \\
\hline 96 & 2 & 217 & 1 & 340 & 2 \\
\hline 97 & 2 & 218 & 1 & & \\
\hline 98 & 1 & 219 & 1 & & \\
\hline 100 & 1 & 220 & 1 & & \\
\hline
\end{tabular}

The total number of dictionary events used is 135 , and the total number of occurrences of these events is 378 . The numerical dictionary is presented in Appendix A.

number of holes in which they occur. This table should be used in conjunction with the numerical code dictionary in Appendix A. As may be readily determined from Table 4, the majority of events are present in a few sites only. All 135 events occur in at least one site, but only one event (the LO of the nannofossil Cruciellipsis cuvillieri) occurs in 11 or more holes. In this study, we will demand that each event in the 13 hole zonation occur in at least three holes, which limits the data to 56 fossil species or magnetic polarity events. Stratigraphically rare, but useful, events for biochronology or correlation may be added to calculated zonations as so-called unique or special events. In essence, this method proceeds such that these special events are placed between the two most adjacent taxon events in the FCSS or Optimum Sequence that also occur in the individual holes in which these special events occur.

The order in which the sites are being processed using GRACOR should not influence the FCSS, which is why more we used more than one cycle of crossplotting. Processing first proceeded 
Table 4. Distribution of dictionary events by the number of holes in which they occur.

\begin{tabular}{rcr}
\hline $\begin{array}{c}\text { Number } \\
\text { of holes }\end{array}$ & $\begin{array}{c}\text { Frequency } \\
\text { of events }\end{array}$ & $\begin{array}{r}\text { Cumulativ } \\
\text { frequency }\end{array}$ \\
\hline 13 & 1 & 1 \\
10 & 1 & 2 \\
8 & 3 & 5 \\
7 & 4 & 9 \\
6 & 4 & 13 \\
5 & 10 & 23 \\
4 & 15 & 38 \\
3 & 18 & 56 \\
2 & 36 & 92 \\
1 & 43 & 135 \\
\hline
\end{tabular}

All 135 events occur in at least one hole, 56 in at least three holes, and so forth; Only one event occurs in at least 11 or more sites ("Cumulative Frequency" column). The "Frequency of Events" column indicates how many taxa occur in $1,2,3$, and so forth, holes.

with all Atlantic sites such that the number of events in common per crossplot was maximized, and then Indian Ocean sites were processed. For each cycle, this order was Sites 534, 391, 603, 105 , $370,535,416,367,387,398,765,261$, and 766 .

Because the event-sequence file includes both first and last occurrences of fossils, the weighted average position (Fig. 3D) was chosen for stratigraphic interpolation using GRACOR. For this reason, the final result of our successive crossplots is a probabilistic zonation that depicts average (first or last occurrence) event positions. When interpolating the designated composite standard sequence with events in the individual hole, event positions in the reference sequence are always based on the weighted average of the old and newly interpolated positions, and the minimum smoothing factor is always used. The spline fit with a minimum smoothing factor minimizes the deviations to all points and maximizes stratigraphic "truthfulness," which is why we prefer it for interpolation. Only in Site 367 did the minimum smoothing factor fail to calculate a best fit, possibly because of violation of monotony during inverse interpolation in the middle part of the section near $940 \mathrm{~m}$, where a condensed sequence appears to exist between Chrons M10 and M11. The average smoothing factor, between the minimum and the maximum (linear best fit) worked fine for Site 367 .

As mentioned, the weight of every event appearing in the crossplot can be varied from -1 (for ignoring it) to +1 (for steering the spline through it) to obtain a satisfactory LOC. In Site 370, Hedbergella delrioensis $\mathrm{FO}(\mathrm{P})$ is far too low stratigraphically and received a weight of -1 . No other event in any other hole was weighted, because the crossplots did not reveal more obvious outliers as a result of random factors.

Events in the Atlantic sites showed tight, often fairly linearly trending scattergrams, with 12 to 32 events in common between the interim FCSS and a hole's record. Spline fitting, with the exception of Site 370, was easy and revealed no obvious hiatuses. The fit between the Atlantic FCSS (after compositing 10 sites) and ODP Site 765 in the eastern Indian Ocean showed more scatter (Fig. 4), although this was not excessive. The largest deviations are shown by the benthic foraminifers, Haplophragmium inconstans LO (coordinates 16-22) and Trochammina quinqueloba LO (coordinates 15-22), both of which occur too low; the planktonic foraminifer, Hedbergella planispira FO (coordinates 3-8); and the dinocyst, Phoberocysta neocomica LO (coor-

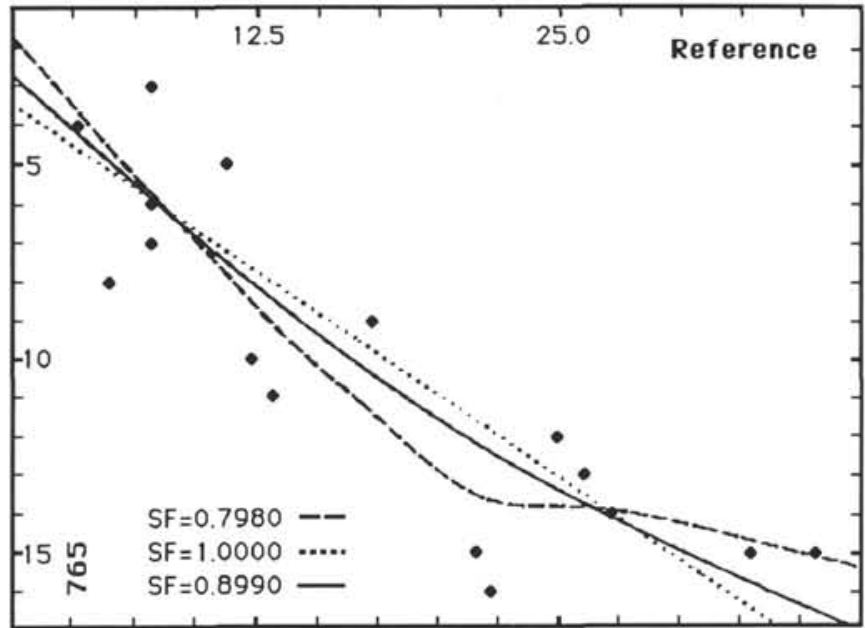

Figure 4. Crossplot of the FCSS, based on 10 Atlantic DSDP sites and the Lower Cretaceous microfossil record in Leg 123 Site 765. The cubic spline fits shown use minimum (dashed line), average (solid line), and maximum (dotted line) smoothing factors. The scale along both axes is based on the number of events per hole. For further explanation, see text.

dinates 5-11), which occurs stratigraphically too high. Crossplots of the FCSS, including 765 with nearby Sites 261 and 766, produce tighter fits, reflecting more local coherence in order.

The process of compositing was repeated twice ( 3 cycles), but the differences between the FCSS in Stage 1, cycle 1 and Stage 1 , cycle 2 , were stratigraphically negligible. No noticeable difference could be seen between the results of cycle 2 and a third cycle 3 , which is why we focused on the FCSS after two cycles.

Figure 5 (right) shows this stabilized FCSS (the results of the second cycle in Stage 1 of GRACOR) with a threshold equal to 3 , and no unique events introduced. The FCSS contains the average stratigraphic position of 56 events, including 6 geomagnetic reversals, 25 nannofossils, 12 dinocysts, 8 benthic, and 5 planktonic foraminifers. Relative event ages progress from Tithonian with Stephanolithion bigotii LO to Albian with Ticinella primula $\mathrm{FO}$ and Eiffellithus turriseiffeli $\mathrm{FO}$.

Figure 5 (left) shows the RASC Optimum Sequence calculated for exactly the same data and the same threshold. Correlation of the order relationship reveals remarkable convergence of stratigraphic order in both solutions. One exception is the average stratigraphic position in each zonal solution of Haplophragmium inconstans LO, Trochammina quinqueloba LO, and Dorothia praehauteriviana FO, all benthic foraminifers, and to a lesser extent, Phoberocysta neocomica LO, Druggidium apicopaucicum, and Odontochitina operculata FO, all dinocysts. We conclude that considerable difference exists among sites in the local stratigraphic ranges of these taxa, which the RASC and STRATCOR methods, each in their own manner, do not resolve satisfactorily without additional occurrence data for these taxa from more sites. Indeed, crossplots using STRATCOR showed above average scatter for these events in some sites, as discussed earlier for the interim FCSS and ODP Site 765 (Fig. 4). Despite this scatter, the RASC and STRATCOR zonal sequences are remarkably similar, which leads us to conclude that both methods are converging on a "true" average biomagnetostratigraphic sequence of events, which may form the basis for a general zonation, as discussed next.

Another way to explore the properties of the data is to treat Indian and Atlantic sites separately, so that regional differences may be maximized. Because this creates two data sets with 10 (Atlantic) and 3 (Indian), respectively, only the STRATCOR 
Praeglobotruncane delrioensis FO (PF)— Praseglobotruncens delrioensis FO (PF

Spinidinium echinoideum FO $(P)$ Spinidinium echinoideum $F O(P)$

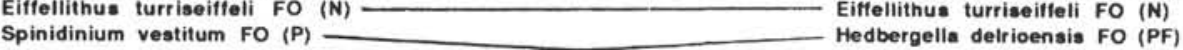

Hedbergells delrioensis FO (PF)—Spinidinium vestitum $F O(P)$

Ticinella primula FO (PP)

Ticinelle primula FO (PF)

Subtilisphaera perlucida LO $(P) —$ Subtilisphaera perlucida LO $(P)$

Druggidium deflandrei $L O(P)$

Hedbergella planispira FO (PF)

Hedbergella

Hedbergella trocoides FO (PF)— Rhagodiscus angustus FO (N)

Rhagodiscus angustus $F O(N)$ Conusphaera mexicana $L O(N)$

Conusphaera mexicana $L O(N)$ Lithastrinus floralis $F O(N)$

Lithastrinus floralis FO $(\mathrm{N}) \longrightarrow$ Gavelinella barremiana LO (BF)

Nannoconus colomii LO (N)

Nannoconus colomii LO $L(N)$ (P)

Chiastozygus litterarius FO (N) — Chistonygus litterarius $F O$ FO (N)

$M 3 r$ top $(M) \longrightarrow$ Druggidium apicopaucicum LO (P

Men rop (M) Mur top (M)

Calcicalathina oblongata $\mathrm{LO}(\mathrm{N}) \longrightarrow$ Malcicalathina oblongata LO $(\mathrm{N})$
Speetonia colligats $\mathrm{LO}(\mathrm{N})$

Speetonia colligats $L O(N)$
Druggidium apicopaucicum $L O(P) \longrightarrow$ Odontochitina operculata $F O(P)$

Cruciellipsis cuvillieri LO $(\mathrm{N}) \longrightarrow$ Speetonis colligata $L O(N)$

MBn top $(M) \longrightarrow$ MBn top (M)

Odontochitina operculata FO $(P)$
Druggidium rhabdoreticulatum FO $(P)$
Cruciellipsis cuvillieri LO (N)
Lenticulina ouachensis LO (BF)

M10n top (M)

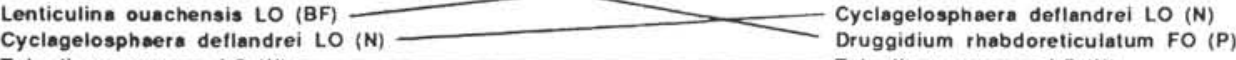

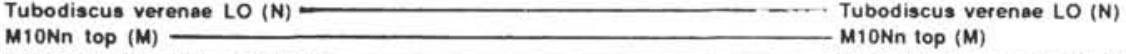

M10Nn top (M)

Diadorhombus rectus $L O(N)$

Trochammina quinquelobs LO (BF)

Diadorhombus

Dorothia praehauteriviana FO $(\mathrm{BF}) \longrightarrow$ Scriniodinium dictyotum LO $(\mathrm{P})$

Lenticulina nodosa FO (BF)

M11n top (M)

Scriniodinium ictyotum FO (N)

Lenticuline busnardoi $L O$ (BF

Druggidium deflandrei $F O(P)$

Aucinolithus wisei LO (N)

Tubodiscus verense $F O(N)$

Lenticulina nodosa FO (BF)

Diadornombus rectus $\mathrm{FO}(\mathrm{N})$

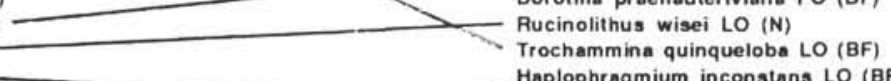

Calcicalathina oblongata FO $(\mathrm{N})$

(N)

Druggidium apicopaucicum FO (P)

Speetonia colligata $F O(N)$

Vagapilla stradneri FO (N)
Biorbiter johnewingii FO (P)

Biorbilera johnewingii FO (P)
Haplophragmium inconstans LO (BF)

Rucinolithus wisei FO (N)

Lithraphidites carniolensis FO
Nannoconus colomi FO

FO (N)

Cruciellipsis cuvillieri FO (N)

Haplophragmium inconstans FO (BF)

Lenticulina busnardoi LO (BF)

ithus wisei LO (N)

Haplophragmium inconstans LO (BF)

Tubodiscus verenae FO (N)

Diadorhombus rectus FO (N)

Calcicalathina oblongata $F O(N)$

Druggidium apicopaucicum FO (P)

Speetonia colligata FO (N)

Vagapilia stradneri FO (N)

Biorbifera johnewingii FO

$\begin{array}{rrr}36 & 1.49 & 3 \\ 263 & 2.08 & 3 \\ 165 & 2.22 & 5 \\ 24 & 2.29 & 4 \\ 266 & 3.01 & 4 \\ 20 & 3.54 & 4 \\ 264 & 3.61 & 3 \\ 256 & 4.03 & 5 \\ 7 & 5.10 & 8 \\ 8 & 5.11 & 5 \\ 176 & 5.30 & 5 \\ 195 & 6.09 & 5 \\ 193 & 6.45 & 3 \\ 60 & 7.43 & 3 \\ 261 & 7.45 & 4 \\ 196 & 7.59 & 4 \\ 157 & 7.71 & 7 \\ 254 & 7.92 & 3 \\ 307 & 8.11 & 3 \\ 309 & 8.62 & 4 \\ 160 & 9.49 & 6 \\ 259 & 10.70 & 8 \\ 187 & 11.49 & 3 \\ 317 & 12.03 & 3 \\ 155 & 12.11 & 13 \\ 76 & 13.68 & 3 \\ 321 & 14.26 & 3 \\ 156 & 15.30 & 4 \\ 257 & 16.24 & 6 \\ 189 & 17.67 & 7 \\ 323 & 17.80 & 3 \\ 163 & 18.54 & 4 \\ 325 & 21.20 & 3 \\ 262 & 22.16 & 3 \\ 74 & 22.23 & 5 \\ 203 & 23.10 & 4 \\ 71 & 23.35 & 4 \\ 255 & 23.72 & 5 \\ 55 & 23.83 & 7 \\ 185 & 24.15 & 7 \\ 88 & 24.34 & 4 \\ 68 & 24.43 & 3 \\ 188 & 26.52 & 10 \\ 204 & 26.84 & 5 \\ 159 & 27.29 & 6 \\ 206 & 27.60 & 4 \\ 253 & 28.51 & 6 \\ 208 & 31.37 & 3 \\ 190 & 32.12 & 4 \\ 251 & 33.25 & 5 \\ 184 & 34.15 & 5 \\ 171 & 35.02 & 4 \\ 154 & 36.32 & 8 \\ 186 & 36.65 & 3 \\ 173 & 36.68 & 4 \\ 67 & 37.89 & 3 \\ 15 & 5.45 & 3 \\ 150\end{array}$

Figure 5. Comparison of the order of latest Jurassic and Early Cretaceous events in the Optimum Sequence using RASC, and the Final Composite Standard Sequence (FCSS) after two cycles using STRATCOR. Each first or last microfossil occurrence event or polarity reversal presence occurs in at least 3 out of 13 sites. The ordering shown is an average of all local order relationships encountered. Most crossovers are stratigraphically insignificant, with larger deviations between the two zonal solutions restricted to a few benthic foraminifers and dinocysts (e.g., the FO or LO events of the agglutinated benthic foraminifers, Haplophragmium inconstans and Trochammina quinqueloba, and the dinocysts, Phoberocysta neocomica and Druggidium apicopaucicum. This larger crossover indicates larger deviations between local and total stratigraphic ranges for these fossils, making these taxa less suitable for correlation. Nannofossils, planktonic foraminifers, and geomagnetic reversals provide the stratigraphically most stable part of the zonations. $\mathrm{FO}=$ first occurrence event; $\mathrm{LO}=$ last occurrence event; $\mathrm{N}=$ calcareous nannofossil; $\mathrm{P}=$ planktonic foraminifer; $\mathrm{M}=$ geomagnetic polarity reversal event; $\mathrm{P}=$ dinocysts (palynomorph); $\mathrm{BF}=$ benthic foraminifer . 
method was used for zonation. RASC does not perform well with three sites, and even 10 sites is not desirable. Rather than thresholding the data severely, we stipulated that for the three Indian Ocean sites, all events must occur in at least one site (hence, no threshold), and for the 10 Atlantic sites, events must occur in a minimum of two sites. Figure 6 shows how well FCSSs correlate for the Atlantic Ocean, retaining 72 events, and the Indian Ocean sites with 66 events. Twenty-two events occur in common between the two regional biomagnetostratigraphic sequences, less than $30 \%$ of the total number of events in each solution. Hence, we conclude that a considerable number of microfossil events are unique to each group of ocean sites. This number should have been slightly less with a threshold of one for both solutions. STRATCOR satifactorily resolves the order of the magnetic polarity chrons, and each FCSS may be considered an optimum sequence for detailed event correlation among local sites in the Tithonian-Albian time interval. Again, as in the supraregional FCSS and RASC sequences of Figure 5, the benthic foraminifers Trochammina quinqueloba $\mathrm{LO}$ and Dorothia praehauteriviana FO, and the dinocyst Phoberocysta neocomica LO show considerable departure from stratigraphic normality among the Atlantic and Indian Ocean sites.

More systematic deviations stand out for some nannofossil events. Cruciellipsis cuvillieri FO appears much later in Indian (Valanginian) than Atlantic Ocean sites (Tithonian). The same is true for Chiastozygus literarius FO, which in the Atlantic sites is Barremian in age and Apian/Albian in the Indian Ocean sites. The FO of Tubodiscus verenae and the LO of Rucinolithis wisei are well below M1 ln (of late Valanginian age in the Atlantic, but adjacent to this chron in the Indian Ocean FCSS, possibly because of some stratigraphic condensation in the Indian Ocean sites during late Valanginian-early Hauterivian time (compare left and right sides of Fig. 7 at M10Nn-M11n positions). These observations would support migration of these taxa from the Atlantic to the Indian Ocean through time. Nevertheless, enough stratigraphic overlap exists between the two zonal sequences to warrant a single, tentative zonation based on stratigraphically average event occurrences, as proposed next. Such an approach trades the ultimate in local resolution for a more practical, generalized stratigraphic "ladder" of events.

Having established that a single FCSS may be of use for a (probabilistic) zonation of both Atlantic and Indian Ocean sites, we depict it in Figure 7. This is the FCSS of Figure 5 (right), but now displayed in dendrogram format to better express interevent distances, indicative of clustering of stratigraphic events along a relative time scale. The dendrogram includes approximately nine assemblage zones of Tithonian through Albian age, using the age connotations for the events in Ogg and Steiner (1988), Gradstein (1986), Kaminski et al. (in press), and the literature cited in Table 1. This FCSS in dendrogram format is an assemblage zonation in which different kinds of fossil and physical events have been quantitatively tied to each other. The positions of the 56 events in the FCSS represent the average stratigraphic interrelation among the events encountered in the 10 Atlantic and three Indian Ocean drilling sites.

The oldest assemblage (No. 1) contains Stephanolithion bigotii $\mathrm{LO}(\mathrm{N})$ of Tithonian age, and the overlying assemblage, No. 2, incorporates the FO of Biorbifera johnewingii $(\mathrm{P})$ and Speetonia colligata $(\mathrm{N})$ of Berriasian age. As may be observed from Figure 6 (left), Chrons M16r and M16n occur in this zone, too (in two Atlantic sites only), and according to Ogg and Steiner (1988), are of Berriasian age. Tubodiscus verenae $\mathrm{FO}(\mathrm{N})$ in assemblage 3 is early Valanginian in age. The next overlying assemblage (No. 4) contains the LO of Lenticulina busnardoi (BF), and the FO of Druggidium deflandrei $(\mathrm{P})$, and Chron M11n, all of late Valan- ginian age. The overlying assemblage 5 has been assigned an early to middle Hauterivian age with the average LO of Tubodiscus verenae $(\mathrm{N})$, the FO of Druggidium rhabdoreticulatum $(\mathrm{P})$, the LO of Cyclagelosphaera deflandrei $(\mathrm{N})$, and Chrons M10N and M10n. The presence of Chron M8, the LO of Cruciellipsis cuvillieri $(\mathrm{N})$, and of Speetonia colligata $(\mathrm{N})$ in assemblage 6 is of latest Hauterivian age. The next overlying assemblage 7 with Chrons M4n, M3r, Calcicalathina oblongata LO (N), and Chiastozygus litterarius $\mathrm{FO}(\mathrm{N})$, is Barremian in age. Assemblage zone 8 with Rhagodiscus angustus $\mathrm{FO}(\mathrm{N})$ and Hedbergella trocoidea FO (PF) is Aptian in age, and in the Atlantic FCSS of Figure 8 (left), also contains Chron M1r. The youngest assemblage zone (No. 9) includes well-known Albian events, such as Ticinella primula $\mathrm{FO}(\mathrm{PF})$ and Eiffelithus turriseiffeli $\mathrm{FO}(\mathrm{N})$.

Incorporation of many more Indian and circum North Atlantic Ocean sites will considerably refine and strengthen this tentative zonation, particularly so when less widespread, but stratigraphically significant radiolarian, cephalopod, and calpionellid data are introduced. The zonation will also provide more insight about diachroneity of events among ocean sites. With this study, we have demonstrated that quantitative processing of DSDP and ODP data leads to a practical Early Cretaceous biomagnetostratigraphic zonation. Higher resolution results when separate zonations can be calculated for each ocean basin.

\section{ZONAL CORRELATION}

Using Stage 2 of STRATCOR, the FCSS of Figure 7 may be crossplotted with the events in each individual hole, now expressed in the original depth unit of measurements (meters below seafloor). Again, the FCSS (dependent variable) is expressed as a function of the individual hole's record (independent variable), using smoothing cubic splines, but now the FCSS is interpolated in each hole to find the most likely (average) local depth of each FCSS event, even if it was not observed locally. The result is summarized in Table 5, which shows the FCSS for the Atlantic and Indian oceans (as discussed above), the measured depth of events observed in each site (Column B), and the interpolated depth of the FCSS events (Column A). Note that often only a small offset is seen between observed and interpolated (average) depths of zonal events, generally less than $10 \mathrm{~m}$. In a few cases, the offset is measured in tens of meters. Blank lines in both columns indicate absence of data for executing spline crossplots between the FCSS and the individual site record.

Using the most likely age in stage units of discrete and stratigraphically reliable events in the FCSS, their interpolated depths may serve as the basis for a most likely chronostratigraphic correlation among oceanic sites. The interested user should have little trouble erecting such a scheme, using, for example, the DNAG (Kent and Gradstein, 1985) or the GTS89 (Harland et al., 1990) time scales. Conversely, the STRATCOR method applied to a much larger, and stratigraphically more refined (pelagic), data set with ammonites, radiolarians, and calpionellids represented may serve to calculate a high-resolution FCSS that can be rescaled in linear time, once enough tiepoints have been established to a standard geological time scale. Thus, a "pelagic" biochronology may be established for the Late Jurassic and Early Cretaceous time interval that can be updated readily.

\section{SUMMARY}

Detailed biostratigraphic data were accumulated during coring of Upper Jurassic and Lower Cretaceous strata in 10 Atlantic and 3 Indian Ocean sites. It is difficult to build an objective multiple biostratigraphic framework by visually comparing range charts of different fossil groups with geomagnetic reversals sequences and scattered fossil records for all 13 sites. The quantitative strati- 


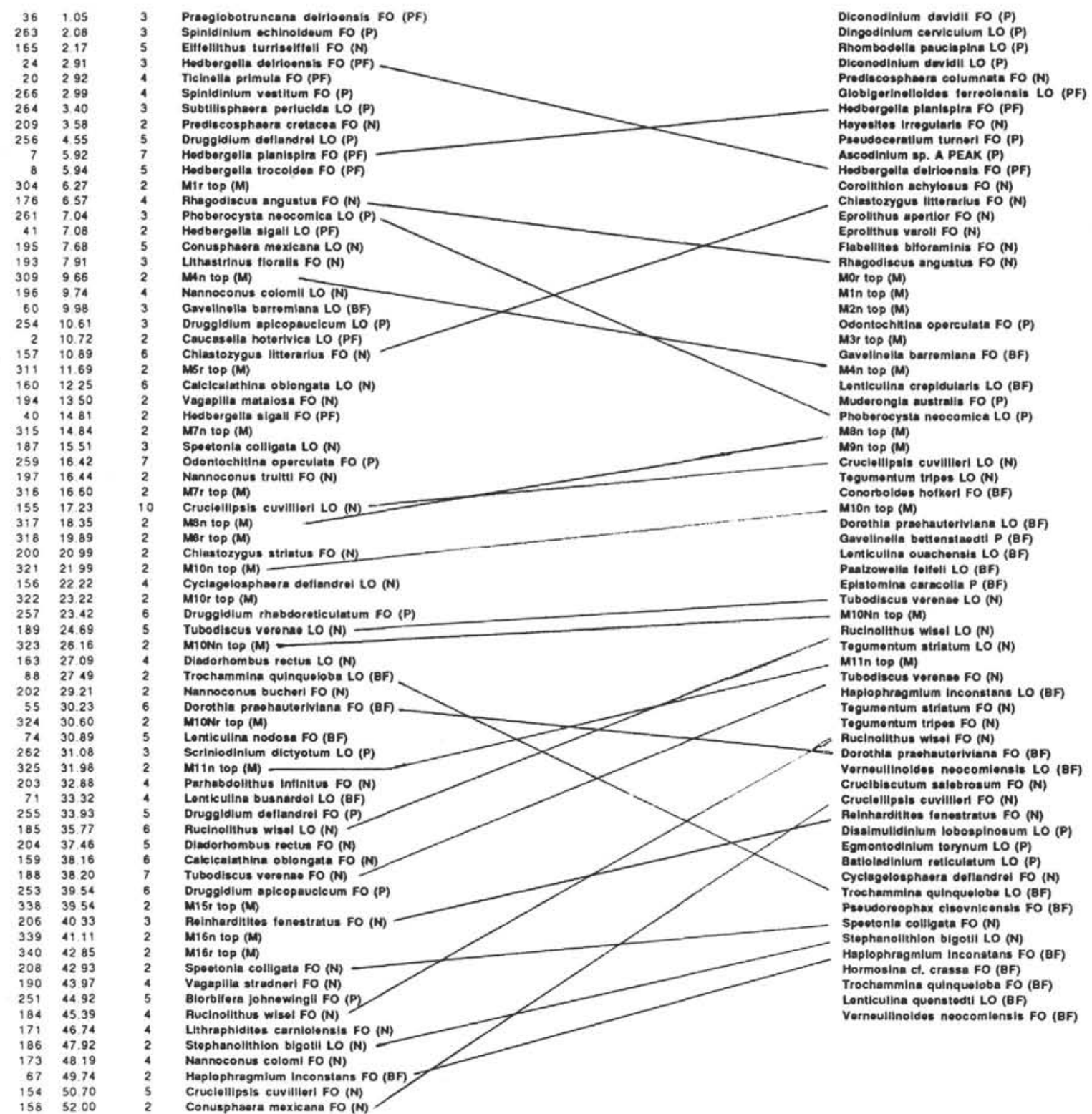

Figure 6. Comparison of the FCSS using STRATCOR for the Lower Cretaceous record in 10 Atlantic DSDP sites (left; 72 events) with the coeval record in 3 Indian Ocean ODP sites (right; 66 events). The Atlantic events occur in at least two holes. The threshold for the Indian Ocean FCSS is 1; hence, it records all events observed in any site. Twenty-two events are in common between the two zonations, with few taxa, such as the LO of the benthic foraminifer Trochammina quinqueloba or the dinocyst Phoberocysta neoconmica showing considerable scatter. 


\section{DENDROGRAM}

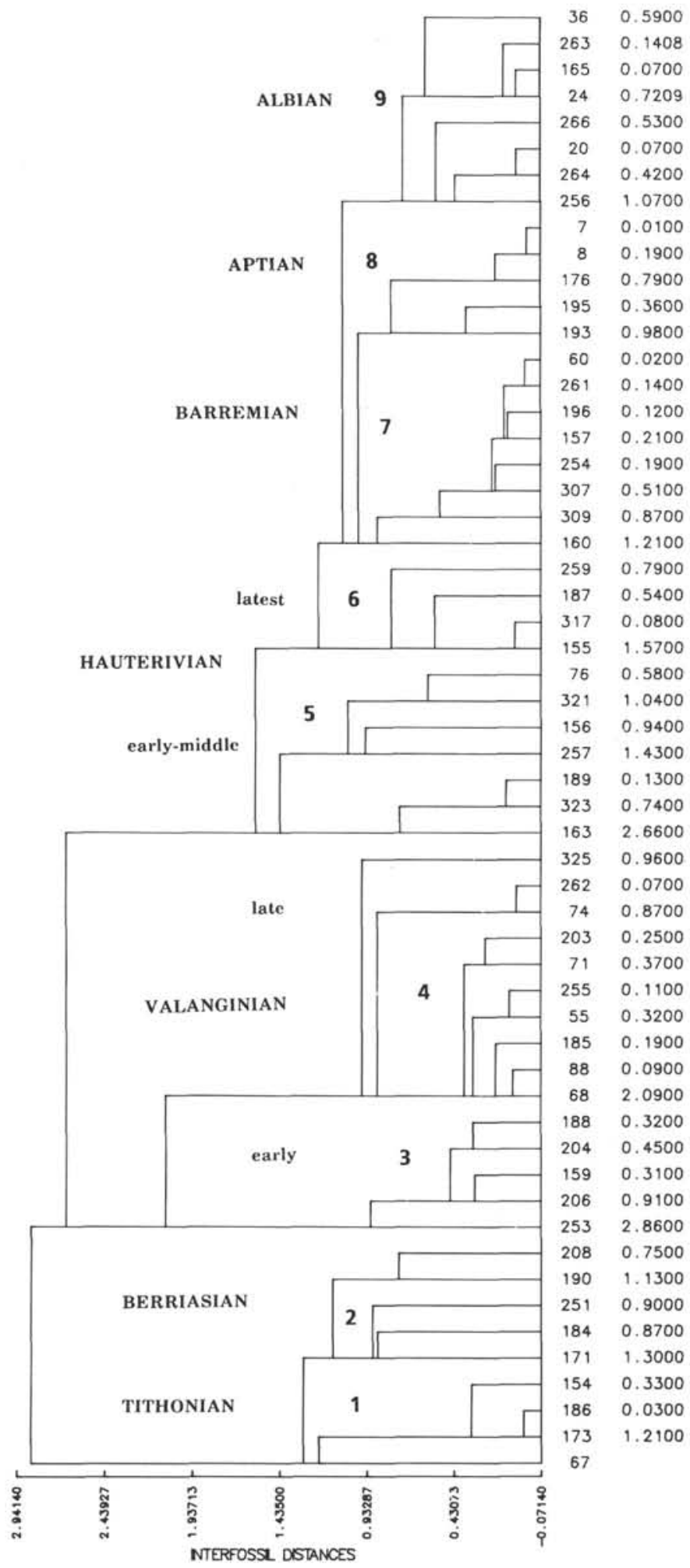

PRAEGLOBOTRUNCANA DELRIOENSIS FO

SPINIDINIUM ECHINOIDEUM FO

EIFFELLITHUS TURRISEIFFELI FO

HEDBERGELLA DELRIOENSIS FO

SPINIDINIUM VESTITUM FO

TICINELLA PRIMULA FO

SUBTILISPHAERA PERLUCIDA LO

DRUGGIDIUM DEFLANDREI LO

HEDBERGELLA PLANISPIRA FO

HEOBERGELLA TROCOIDEA FO

RHAGODISCUS ANGUSTUS FO

CONUSPHAERA MEXICANA LO

LITHASTRINUS FLORALIS FO

GAVELINELLA BARREMIANA LO

PHOBEROCYSTA NEOCOMICA LO

NANNOCONUS COLOMII LO

CHIASTOZYGUS LITTERARIUS FO

DRUGGIDIUM APICOPAUCICUM LO

M3R TOP

M 4N TOP

CALCICALATHINA OBLONGATA LO

ODONTOCHITINA OPERCULATA FO

SPEETONIA COLLIGATA LO

MBN TOP

CRUCIELLIPSIS CUVILLIER! LO

LENTICULINA OUACHENSIS LO

MION TOP

CYCLAGELOSPHAERA DEFLANDREI LO DRUGGIDIUM RHABDORETICULATUM FO

TUBODISCUS VERENAE LO

MIONN TOP

DIADORHOMBUS RECTUS LO

MIIN TOP

SCRINIODINIUM DICTYOTUM LO

LENTICULINA NODOSA FO

PARHABDOLITHUS INFINITUS FO

LENTICULINA BUSNARDOI LO

DRUGGIDIUM DEFLANDREI FO

DOROTHIA PRAEHAUTERIVIANA FO

RUCINOLITHUS WISEI LO

TROCHAMMINA QUINQUELOBA LO

HAPLOPHRAGMIUM INCONSTANS LO

TUBODISCUS VERENAE FO

DIADORHOMBUS RECTUS FO

CALCICALATHINA OBLONGATA FO

REINHARDITITES FENESTRATUS FO

DRUGGIDIUM APICOPAUCICUM FO

SPEETONIA COLLIGATA FO

VAGAPILLA STRADNERI FO

BIORBIFERA JOHNEWINGII FO

RUCINOLITHUS WISEI FO

LITHRAPHIDITES CARNIOLENSIS FO

CRUCIELLIPSIS CUVILLIERI FO

STEPHANOLITHION BIGOTII LO

NANNOCONUS COLOMI FO

HAPLOPHRAGMIUM INCONSTANS FO

Figure 7. Dendrogram of the FCSS in Figure 6 (right) for 56 latest Jurassic through Early Cretaceous microfossil and magnetic polarity events in 13 DSDP and ODP sites, Atlantic and Indian oceans. The stratigraphic positions are averages of all local relative positions encountered. Nine successive assemblage zones may be differentiated, of Tithonian through Albian age, that form the basis for correlation of the sites in Table 5 . 


\begin{tabular}{|c|c|c|c|c|c|c|c|c|c|c|c|c|c|c|c|}
\hline \multirow[b]{2}{*}{ Code } & \multirow[b]{2}{*}{ Events } & \multicolumn{2}{|c|}{ DSDP $534 \mathrm{~A}$} & \multicolumn{2}{|c|}{ DSDP $391 \mathrm{C}$} & \multicolumn{2}{|c|}{ DSDP 603B } & \multicolumn{2}{|c|}{ DSDP 105} & \multicolumn{2}{|c|}{ DSDP 370} & \multicolumn{2}{|c|}{ DSDP 535A } & \multicolumn{2}{|c|}{ DSDP $416 \mathrm{~A}$} \\
\hline & & A & B & A & B & A & B & A & B & A & B & A & B & A & B \\
\hline 36 & Praeglobotruncana delrioensis FO (PF) & 763.30 & 774 & - & - & - & - & - & - & 731.70 & 740.00 & - & - & - & - \\
\hline 263 & Spinidinium echinoideum FO (P) & 793.03 & 793 & - & - & 1169.61 & 1170 & 335.23 & 309.00 & 752.72 & - & - & - & - & - \\
\hline 165 & Eiffellithus turriseiffeli $\mathrm{FO}(\mathrm{N})$ & 800.33 & - & - & - & 1172.25 & - & 339.54 & 322.00 & 757.96 & 733.00 & - & - & - & - \\
\hline 24 & Hedbergella delrioensis $\mathrm{FO}(\mathrm{PF})$ & 803.92 & 774 & & - & 1173.52 & -- & 341.61 & - & 760.56 & - & - & - & 732.98 & 730.00 \\
\hline 266 & Spinidinium vestitum $\mathrm{FO}(\mathrm{P})$ & 843.91 & 863 & 811.50 & 784 & 1187.10 & 1188 & 363.04 & 388.00 & 788.89 & - & & & 753.44 & - \\
\hline 20 & Ticinella primula FO (PF) & 872.18 & & 852.20 & - & 1197.19 & - & 377.25 & - & 806.45 & 816.00 & 327.90 & 326.00 & 768.39 & - \\
\hline 264 & Subtilisphaera perlucida LO (P) & $\$ 75.58$ & 863 & 857.11 & - & 1198.46 & - & 378.91 & 392.00 & 808.22 & 827.00 & 330.63 & - & 770.25 & - \\
\hline 256 & Druggidium deflandrei LO (P) & 896.46 & 908 & 886.53 & 926 & 1206.75 & 1210 & 388.80 & 404.00 & 816.96 & & 347.93 & - & 782.16 & -- \\
\hline 7 & Hedbergella planispira FO (PF) & 937.05 & 941 & 940.86 & - & 1228.88 & 1220 & 407.94 & -. & 827.01 & 828.00 & 384.34 & 368.00 & 811.10 & 855.00 \\
\hline 8 & Hedbergella trocoidea $\mathrm{FO}(\mathrm{PF})$ & 937.25 & - & 941.14 & 927 & 1229.04 & - & 408.04 & & 827.06 & 816.00 & 384.53 & 404.00 & 811.28 & - \\
\hline 176 & Rhagodiscus angustus $\mathrm{FO}(\mathrm{N})$ & 942.75 & - & 948.79 & 963 & 1233.54 & & 410.78 & & 828.43 & 829.00 & 389.34 & & 816.47 & 764.00 \\
\hline 195 & Conusphaera mexicana LO (N) & 958.99 & 965 & 974.38 & 963 & 1252.85 & 1255 & 419.70 & & 835.20 & & 402.34 & 403.00 & 837.12 & - \\
\hline 193 & Lithastrinus floralis FO (N) & 963.81 & - & 984.50 & & 1262.22 & - & 422.84 & & 839.37 & 829.00 & 405.69 & - & 846.45 & - \\
\hline 60 & Gavelinella barremiana LO (BF) & 972.77 & & 1007.63 & 1009 & 1287.63 & - & 428.72 & & 852.68 & 876.00 & 411.41 & - & 869.67 & - \\
\hline 261 & Phoberocysta neocomica LO (P) & 972.98 & 968 & 1008.13 & - & 1288.25 & 1238 & 428.83 & & 852.98 & 80.00 & 411.56 & 402.00 & 870.19 & - \\
\hline 196 & Nannoconus colomii LO (N) & 974.25 & - & 1010.92 & 1010 & 1291.78 & & 429.40 & & 854.62 & 840.00 & 412.42 & - & 873.16 & - \\
\hline 157 & Chiastozygus litterarius $\mathrm{FO}(\mathrm{N})$ & 975.38 & - & 1013.23 & 1019 & 1294.71 & 1324 & 429.85 & - & 855.97 & -- & 413.14 & 422.00 & 875.62 & 897.00 \\
\hline 254 & Druggidium apicopaucicum LO (P) & 977.63 & - & 1017.27 & 1012 & 1299.71 & 1347 & 430.59 & 426.00 & 858.35 & & 414.21 & & 879.95 & - \\
\hline 307 & M3r top (M) & 979.85 & - & 1020.71 & - & 1303.71 & - & 431.17 & & 860.36 & & 414.93 & & 883.63 & - \\
\hline 309 & M4n top (M) & 987.20 & 983 & 1029.52 & - & 1313.18 & 1292 & 432.39 & & 865.44 & & 416.24 & - & 892.97 & \\
\hline 160 & Calcicalathina oblongata LO (N) & 1005.39 & 991 & 1043.34 & 1030 & 1328.18 & 1320 & 433.54 & - & 873.10 & - & 418.66 & - & 907.25 & - \\
\hline 259 & Odontochitina operculata FO (P) & 1036.12 & 1074 & 1057.51 & 1091 & 1347.95 & 1373 & 433.94 & 433.00 & 882.37 & 885.00 & 430.72 & 421.00 & 925.10 & - \\
\hline 187 & Speetonia collig ata LO $(\mathrm{N})$ & 1050.53 & 1018 & 1058.83 & - & 1359.54 & 1330 & 433.96 & & 888.57 & & 448.81 & 459.00 & 936.80 & - \\
\hline 317 & M8n top (M) & 1061.71 & 1073 & 1059.82 & - & 1368.90 & 1381 & 434.04 & - & 894.08 & & 448.59 & - & 945.30 & - \\
\hline 155 & Cruciellipsis cuvill & 1063.42 & 1057 & 1060.21 & 1031 & 1370.34 & 1360 & 434.06 & 430.00 & 895.01 & 891.00 & 448.81 & 444.00 & 946.57 & 982.00 \\
\hline 76 & Lenticulina ouachensis LO (BF) & 1097.50 & - & 1083.28 & - & 1400.02 & - & 435.29 & - & 922.10 & - & 450.15 & - & 980.18 & 900.00 \\
\hline 321 & M10n top (M) & 1106.99 & 1112 & 1095.71 & - & 1408.86 & 1423 & 436.10 & - & 935.41 & - & 451.69 & - & 999.41 & - \\
\hline 156 & Cycla & 1115.52 & 1130 & 111 & 1126 & 1418 & 1427 & 438.03 & & 962 & - & 460.78 & - & 1042.29 & - \\
\hline 257 & Druggidium rhabdoreticulatum $\mathrm{F}$ & 1116.58 & 1099 & 1129.49 & 1131 & 1424.89 & 1404 & 440.29 & 440.00 & 989.18 & - & 480.40 & 478.00 & 1085.86 & - \\
\hline 189 & Tubodiscus verenae $\mathrm{LO}(\mathrm{N})$ & 1127.51 & 1127 & 1139.24 & 1137 & 1438.31 & 1446 & 444.58 & - & 1030.93 & - & 533.98 & 531.00 & 1149.50 & 1188.00 \\
\hline 323 & M10 & 1129.14 & 1128 & 113 & - & 143 & 1447 & 445.04 & - & 1034.87 & - & 539.94 & - & 11 & - \\
\hline 163 & Diadorhombus rectus LO (N) & 1138.62 & 1143 & 1142.69 & - & 1446.95 & 1436 & 447.67 & - & 1055.60 & - & 570.29 & 576.00 & 1181.55 & 1199.00 \\
\hline 325 & M11n top (M) & 1169.20 & 1172 & 1153.38 & - & 1479.82 & 1493 & 458.73 & - & 1114.29 & & 614.22 & - & 1250.97 & - \\
\hline 262 & Scrin & 1179.16 & 1193 & 1160.36 & - & 1492.14 & 1476 & 463.24 & 459.00 & 112 & _- & 620 & - & 127. & - \\
\hline 74 & Lenticulina nodosa FO (BF) & 1179.84 & 1167 & 1160.91 & 1147 & 1493.02 & - & 463.54 & 469.00 & 1126.20 & 1129.00 & 621.45 & - & 1276.16 & 1303.00 \\
\hline 203 & Parhabdolithus infinitus FO (N) & 1191.85 & 1189 & 1168.69 & 1198 & 1507.28 & - & 467.78 & - & 1130.18 & - & 632.88 & 611.00 & 1301.66 & - \\
\hline 71 & Lentic & 1196.42 & - & 1170.32 & - & 1511.80 & 1509 & 469.05 & - & 1130.48 & 1139.00 & 637.52 & 660.00 & 1310.44 & 1222.00 \\
\hline 255 & Druggidium deflandrei $\mathrm{FO}(\mathrm{P})$ & 1204.06 & 1205 & 1172.37 & 1177 & 151 & 1518 & 470.91 & 484.00 & 1130.53 & & 642.57 & - & 1324.55 & - \\
\hline 55 & Dorothia praehauteriviana FO (BF) & 1206.63 & 1167 & 1173.03 & 1147 & 1520.41 & 1509 & 471.48 & 457.00 & 1130.56 & 1120.00 & 643.67 & - & 1329.16 & 1400.00 \\
\hline 185 & ei LO (N) & 1214.44 & 1223 & 1175.23 & 1178 & 1525.97 & 1546 & 473.17 & & 1130.89 & - & 645.89 & & 1343.11 & 1391.00 \\
\hline 88 & Troch & 1218.80 & 1149 & 1176.69 & - & 1528.97 & - & 474.17 & & 1131 & & 64 & $\ldots$ & 1351.81 & 1198.00 \\
\hline 68 & Haplophragmium inconstans LO (BF) & 1220.71 & 1332 & 1177.42 & - & 1530.33 & - & 474.66 & & 1131.49 & 1. & 646.91 & & 1356.12 & - \\
\hline 188 & Tubodiscus verenae $\mathrm{FO}(\mathrm{N})$ & 1231.98 & 1230 & 1198.20 & 1198 & 1548.54 & 1556 & 487.07 & & 1144.77 & 1140.00 & 652.98 & 648.00 & 1468.03 & 1531.00 \\
\hline 204 & Diadorhombus rectus $\mathrm{FO}(\mathrm{N})$ & 1233.36 & 1207 & 1201.31 & 1199 & 1549.02 & 1565 & 489.11 & & 1148.05 & & 657.39 & - & 1483.07 & - \\
\hline 159 & Calcicalathina oblongata FO (N) & 1237.21 & 1230 & 1205.28 & 1210 & 1549.13 & 1526 & 492.03 & & 1152.71 & 1158.00 & 665.17 & - & 1501.96 & 1531.00 \\
\hline 206 & Reinharditites fenestratus $\mathrm{FO}(\mathrm{N})$ & 1240.44 & 1269 & 1207.60 & 1210 & 1549.34 & - & 494.12 & & 1155.69 & - & 670.84 & 675.00 & 1513.52 & - \\
\hline 253 & Druggidium apicopaucicum FO (P) & 1247.54 & 1243 & 1212.27 & 1212 & 1551.38 & 1549 & 500.20 & 504.00 & 1162.68 & - & 684.98 & 684.00 & 1539.32 & - \\
\hline 208 & Speetonia colligata FO (N) & 1273.25 & 1272 & 1224.99 & & 1566.75 & 1570 & 522.18 & sento & 1174.55 & - & - & -0 & 1570.62 & - \\
\hline 190 & Vagap & 1283.51 & 1288 & 1232.44 & 1229 & 1570.40 & & 529.49 & - & 1176.39 & 1176.00 & - & - & 1571.56 & - \\
\hline 251 & Biorbifera johnewingii FO (P) & 1303.59 & 1287 & 1249.85 & 1263 & 1575.11 & 1574 & 542.49 & 533.00 & - & - & - & - & 1571.77 & - \\
\hline 184 & Rucinolithus wisei $\mathrm{FO}(\mathrm{N})$ & 1325.03 & 1331 & 1270.11 & 1238 & - & - & 554.85 & - & - & - & - & - & 1573.18 & 1560.00 \\
\hline 171 & Lithraphidites carniolensis & 1341.87 & 1353 & 1298.13 & 131 & - & - & 567.90 & - & & -. & - & .. & 1577.32 & 1559.00 \\
\hline 154 & Cruciellipsis cuvillieri $\mathrm{FO}(\mathrm{N})$ & 1351.04 & 1359 & 1338.76 & 1372 & - & - & 588.30 & 603.00 & & - & - & - & 1588.74 & 1615.00 \\
\hline 186 & Stephanolithion bigotii LO (N) & 1351.30 & 1350 & 1347.17 & & - & - & 593.44 & 585.00 & & & - & - & 1592.19 & - \\
\hline 173 & colomi $\mathrm{FO}(\mathrm{N})$ & 1351.31 & 1340 & 1347.99 & 1321 & - & - & - & & & & - & & 1592.55 & 1572.00 \\
\hline 67 & Haplophragmium inconstans FO (BF) & 1351.90 & 1352 & - & - & - & - & - & & & . & - & - & 1606.57 & 1616.00 \\
\hline
\end{tabular}

To the extreme left is the FCSS; Column B contains the measured depth per site of the actually observed record; the interpolated (average) depth for the events in the FCSS is in Column A. Dashes in both columns indicate absence of data for executing spline crossplots between zonation and individual site record. 
Table 5 (continued),

\begin{tabular}{|c|c|c|c|c|c|c|c|c|c|c|c|c|c|}
\hline \multirow[b]{2}{*}{ Code } & \multirow[b]{2}{*}{ Events } & \multicolumn{2}{|c|}{ DSDP 398d } & \multicolumn{2}{|c|}{ DSDP 367} & \multicolumn{2}{|c|}{ DSDP 387} & \multicolumn{2}{|c|}{ ODP 765} & \multicolumn{2}{|c|}{ DSDP 261} & \multicolumn{2}{|c|}{ ODP 766} \\
\hline & & A & B & A & B & A & в & A & B & A & B & A & B \\
\hline 36 & Praeglobotruncana delrioensis $\mathrm{FO}(\mathrm{PF})$ & - & - & 698.80 & 701.00 & - & & - & & & & & - \\
\hline 263 & Spinidinium echinoideum FO $(\mathrm{P})$ & - & 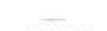 & 711.46 & - & - & - & - & - & - & - & & - \\
\hline 165 & Eiffellithus turriseiffeli $\mathrm{FO}(\mathrm{N})$ & 994.37 & 993.00 & 714.43 & 727.00 & 474.49 & 469.00 & - & - & - & - & - & - \\
\hline 24 & Hedbergella delrioensis $\mathrm{FO}(\mathrm{PF})$ & 1009.36 & & 715.86 & 730.00 & 477.85 & & 729.51 & 721.00 & & & -. & .. \\
\hline 266 & Spinidinium vestitum $F O(P)$ & 1160.45 & & 731.46 & - & 513.01 & & 738.26 & - & & & & \\
\hline 20 & Ticinella primula FO (PF) & 1245.67 & 1250.00 & 743.82 & 730.00 & 536.89 & & 744.69 & & & & & - \\
\hline 264 & Subtilisphaera perlucida LO (P) & 1253.89 & - & 745.45 & - & 539.69 & & 745.50 & $=$ & & & & \\
\hline 256 & Druggidium deflandrei $\mathrm{LO}(\mathrm{P})$ & 296.21 & - & 756.49 & - & 556.39 & 565.00 & 750.68 & - & - & & - & - \\
\hline 7 & Hedbergella planispira FO (PF) & 1419.97 & 1345.00 & 788.83 & 787.00 & 587.21 & - & 763.58 & 712.00 & & & & -. \\
\hline 8 & Hedbergella trocoidea $\mathrm{FO}(\mathrm{PF})$ & 1421.31 & 1468.00 & 789.07 & 701.00 & 587.37 & - & 763.66 & & & & & - \\
\hline 176 & Rhagodiscus angustus $\mathrm{FO}(\mathrm{N})$ & 1460.02 & $1487.06)$ & 795.91 & - & 591.62 & $\ldots$ & 766.04 & 726.00 & & & & - \\
\hline 195 & Conusphaera mexicana $\mathrm{LO}(\mathrm{N})$ & 1554.58 & - & 824.94 & - & 605.54 & 603.00 & 775.52 & - & & & & \\
\hline 193 & Lithastrinus floralis $\mathrm{FO}(\mathrm{N})$ & 1572.06 & 1571.00 & 838.41 & 891.00 & 610.70 & - & 779.89 & - & & & & \\
\hline 60 & Gavelinella barremiana LO (BF) & 1585.09 & 1591.00 & 870.99 & & 621.31 & & 791.33 & & & & & \\
\hline 261 & Phoberocysta neocomica LO (P) & 1585.09 & - & 871.71 & - & 621.52 & & 791.61 & 863.00 & & & & \\
\hline 196 & Nannoconus colomii LO (N) & 1585.33 & 1573.00 & 875.73 & 897.00 & 622.65 & .- & 793.18 & - & & & & - \\
\hline 157 & Chiastozygus litterarius FO (N) & 1586.28 & 1592.00 & 879.04 & 891.00 & 623.56 & & 794.50 & 724.00 & & & -. & \\
\hline 254 & Druggidium apicopaucicum LO (P) & 1588.83 & - & 884.80 & & 625.08 & & 796.91 & & & & - & - \\
\hline 307 & M3r top (M) & 1591.70 & & 889.63 & & 626.29 & & 799.02 & 833.00 & 417.96 & 404.00 & 276.15 & 259.00 \\
\hline 309 & M4n top (M) & 1602.01 & & 901.45 & - & 628.97 & - & 804.66 & 845.00 & 422.44 & 438.00 & 284.82 & - \\
\hline 160 & Calcicalathina oblongata LO (N) & 1625.93 & 1626.00 & 917.81 & 916.00 & 631.76 & 632.00 & 813.97 & - & 429.73 & $\ldots$ & 299.66 & - \\
\hline 259 & Odontochitina operculata FO (P) & 1665.48 & - & 933.67 & - & 632.96 & 633.00 & 826.04 & 816.00 & 439.05 & - & 320.02 & - \\
\hline 187 & Speetonia colligata LO $(\mathbb{N})$ & 1693.53 & - & 940.67 & - & 633.01 & - & 833.39 & - & 444.80 & & 333.17 & \\
\hline 317 & M8n top $(M)$ & 1713.16 & - & 944.27 & - & 633.10 & -- & 838.15 & - & 448.64 & - & 342.05 & 346.00 \\
\hline 155 & Cruciellipsis cuvillieri LO (N) & 1715.98 & 1716.00 & 944.72 & 940.00 & 633.14 & 633.00 & 838.81 & 873.00 & 449.18 & 447.00 & 343.31 & 272.00 \\
\hline 76 & Lenticulina ouachensis LO (BF) & - & - & 950.93 & - & 635.92 & - & 851.19 & 882.00 & 459.91 & - & 368.10 & 422.00 \\
\hline 321 & M10n top (M) & - & - & 952.09 & - & 638.48 & 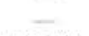 & 855.27 & - & 463.73 & & 376.70 & 400.00 \\
\hline 156 & Cyclagelosphaera deflandrei $\mathrm{LO}(\mathrm{N})$ & & - & 953.15 & -. & 646.16 & 642.00 & 861.99 & - & 470.33 & & 391.20 & - \\
\hline 257 & Druggidium rhabdoreticulatum FO (P) & - & - & 953.39 & - & 656.54 & 660.00 & 867.42 & - & 475.96 & & 403.23 & - \\
\hline 189 & us verenae $\mathrm{LO}(\mathrm{N})$ & -- & - & 953.53 & -- & 672.91 & - & 874.57 & 866.00 & 483.78 & & 419.39 & 443.00 \\
\hline 323 & M10Nn top (M) & - & - & 953.58 & - & 674.45 & - & 875.19 & - & 484.48 & & 420.80 & 425.00 \\
\hline 163 & Diadorhombus rectus LO (N) & - & - & 954.09 & - & 682.71 & $\ldots$ & 878.37 & & 488.07 & & 428.04 & - \\
\hline 325 & M1ln top (M) & - & & 962.19 & - & 711.56 & & 887.47 & - & 489.23 & & 448.98 & 441.00 \\
\hline 262 & Scriniodinium dictyotum LO (P) & - & & 969.00 & - & 721.87 & $\ldots$ & 889.99 & - & 500.71 & & 454.92 & - \\
\hline 74 & Lenticulina nodosa FO (BF) & & & 969.52 & - & 722.52 & - & 890.14 & - & 500.84 & & 455.27 & - \\
\hline 203 & Parhabdolithu & & & 978.28 & 941.00 & 731.79 & - & 892.08 & -. & 502.40 & & 459.92 & - \\
\hline 71 & Lenticulina busnardoi LO (BF) & -. & & 981.31 & - & 734.47 & - & 892.59 & - & 502.73 & & 461.15 & - \\
\hline 255 & Drusgidium deflandrei $\mathrm{FO}(\mathrm{P})$ & - & & 985.94 & - & 738.35 & 735.00 & 893.28 & - & 503.11 & & 462.85 & - \\
\hline 55 & zuteriviana FO (BF) & - & & 987.39 & & 739.53 & & 893.49 & 893.00 & 503.20 & & 463.35 & \\
\hline 185 & Rucinolithus wisei LO (N) & - & & 991.57 & 1024.00 & 742.85 & 746.00 & 894.05 & 883.00 & 503.40 & & 464.73 & \\
\hline 88 & Trochammina quinqueloba LO (BF) & - & & 994.00 & - & 774.70 & - & 894.36 & 908.00 & 503.47 & 525.00 & 465.50 & $\ldots$ \\
\hline 68 & Haplophragmium inconstans LO (BF) & $\ldots$ & & 995.14 & - & 745.56 & -. & 894.51 & 891.00 & 503.50 & 494.00 & 465.86 & - \\
\hline 188 & Tubodiscus verenae $\mathrm{FO}(\mathrm{N})$ & & & 1020.31 & - & 760.07 & 773.00 & 897.26 & 892.00 & 504.29 & 487.00 & 472.81 & 471.00 \\
\hline 204 & Diadorhombus rectus $\mathrm{FO}(\mathrm{N})$ & & & 1023.86 & 1024.00 & 761.38 & 746.00 & 897.58 & -. & 504.84 & & 473.65 & - \\
\hline 159 & na oblongata FO ( & - & & 1028.73 & - & 763.60 & 765.00 & 897.99 & - & 505.90 & & 474.74 & \\
\hline 206 & Reinharditites fenestratus FO (N & - & & 1032.04 & - & 765.38 & - & 898.26 & - & 506.82 & 506.00 & 475.44 & - \\
\hline 253 & Druggidium apicopaucicum $\mathrm{FO}(\mathrm{P})$ & & & 1041.03 & - & 770.82 & 772.00 & 898.91 & $\ldots$ & 510.00 & - & 477.18 & - \\
\hline 208 & Speetonia colligata FO (N) & - & & 1064.77 & - & 784.87 & - & 900.08 & - & 520.40 & 532.00 & 480.54 & - \\
\hline 190 & Vagapilla stradneri $\mathrm{FO}(\mathrm{N})$ & - & - & 1069.71 & - & 787.43 & 788.00 & 900.22 & - & 521.81 & - & 480.98 & - \\
\hline 251 & Biorbifera johnewingii FO (P) & - & $\ldots$ & 1076.10 & - & 790.53 & 790.00 & 900.34 & - & 522.79 & & 481.41 & - \\
\hline 184 & Rucinolithus wisei $\mathrm{FO}(\mathrm{N})$ & - & & 1180.29 & 1083.00 & . & - & 900.39 & 893.00 & 523.04 & & 481.59 & - \\
\hline 171 & Lithraphidites carniolensis $\mathrm{FO}(\mathrm{N})$ & & & 1083.55 & 1085.00 & - & - & 900.42 & - & 523.23 & & 481.68 & - \\
\hline 154 & Cruciellipsis cuvillieri FO (N) & & & 1087.46 & 1087.00 & & - & 900.43 & 893.00 & 524.20 & 507.00 & 481.70 & 471.00 \\
\hline 186 & Stephanolithion bigotii LO (N) & - & & 1088.36 & - & & -. & - & - & 524.69 & 532.00 & - & - \\
\hline 173 & Nannoconus colomi FO (N) & - & - & 1088.45 & 1085.00 & & & - & - & 524.74 & & $\therefore$ & - \\
\hline 67 & Haplophragmium inconstans FO (BF) & - & & - & 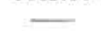 & - & - & - & - & 527.04 & 532.00 & - & - \\
\hline
\end{tabular}


graphic methods, STRATCOR and RASC, provide powerful and efficient tools for solving this problem. STRATCOR also is suited for smaller data sets, such as those encountered here.

The STRATCOR-derived Final Composite Standard Sequence (FCSS) displays the most likely, average order of 56 stratigraphic events based on geomagnetic reversals and the average range endpoints of nannofossils, planktonic and benthic foraminifers, and dinocysts. Each event occurs in at least three sites. Nine assemblage zones of Tithonian through Albian age are proposed; the zonation may be refined using more data, although for optimum resolution, it is best to erect separate Atlantic and Indian Ocean zonations. Using STRATCOR, the FCSS also is correlated through all ocean sites.

\section{ACKNOWLEDGMENTS}

This study and its manuscript benefitted from scientific advice provided by Inger Lise Kristiansen, Mike Kaminski, Jurgen Mutterlose, and Sherwood Wise. Doug Williams, Frits Agterberg, and Jill Mutschler-Fontenot suggested improvements of the manuscript. We are grateful for the support provided by these colleagues. Art Jackson and Frank Thomas, Dartmouth, Nova Scotia, gave valuable technical assistance. The authors acknowledge financial support for this study from the Geological Survey of Canada (to FMG and DM), the National Science and Engineering Research Council (NSCERC) (to $\mathrm{ZH}$ ), and the National Science Foundation (to JGO).

\section{REFERENCES}

Agterberg, F. P., 1990. Automated Stratigraphic Correlation: New York (Elsevier).

Agterberg, F. P., Gradstein, F. M., Nel, L. D., Lew, S. N., Heller, M., Gradstein, W. S., D'Iorio, M. D., Gillis, D., and Huang, Z., 1989. Program RASC (ranking and scaling). Com. Quant. Stratigr. IUGS, Version 12 (manual and diskette).

Blechschmidt, C., 1979. Biostratigraphy of calcareous nannofossils: Leg 47B, Deep Sea Drilling Project. In Sibuet, J., Ryan, W.B.F., et al., Init. Repts. DSDP, 47(Pt. 2): Washington(U.S. Govt. Printing Oifice), 327-360.

Cepek, P., 1978. Mesozoic calcareous nannoplankton of the eastern North Atlantic, Leg 41. In Lancelot, Y., Seibold, E., et al., Init. Repts. DSDP, 41: Washington (U.S. Govt. Printing Office), 667-688.

Cepek, P., Gartner, S., and Cool, T., 1980. Mesozoic calcareous nannofossils, Deep Sea Drilling Project Sites 415 and 416, Moroccan Basin. In Lancelot, Y., Winterer, E. L., et al., Init. Repts. DSDP, 50: Washington (U.S. Govt. Printing Office), 345-354.

Covington, J. M., and Wise, S. W., Jr., 1987. Calcareous nannofossil biostratigraphy of a Lower Cretaceous deep-sea fan complex, Deep Sea Drilling Project Leg 93, Site 603, lower continental rise off Cape Hatteras. In van Hinte, J. E., Wise, S. W., Jr., et al., Init. Repts. DSDP, 93 (Pt. 2): Washington (U.S. Govt. Printing Office), 617-660.

Edwards, L. E., 1984. Insight on why graphic correlation (Shaw's method) works. J. Geol., 92:583-597.

Gradstein, F. M., 1978a. Foraminifera from DSDP Site 370, Leg 41, eastern North Atlantic Ocean. In Talwani, M., Udintsev, G., et al., Init. Repts. DSDP, 38-41 (Supplement to Vols. XXXVIII, XXXIX, $\mathrm{XL}$, and XLI): Washington (U.S. Govt. Printing Office), 779-782.

1978b. Biostratigraphy of Lower Cretaceous Blake Nose and Blake-Bahama Basin foraminifers, DSDP Leg 44, western North Atlantic Ocean. In Benson, W. E., Sheridan, R. E., et al., Init. Repts. DSDP, 44: Washington (U.S. Govt. Printing Office), 663-702.

1983. Paleoecology and stratigraphy of Jurassic abyssal foraminifera in the Blake-Bahama Basin, Deep Sea Drilling Project Leg 76, Sites 533 and 534. In Gradstein, F. M., Sheridan, R. E., et al., Init. Repts. DSDP, 76: Washington (U.S. Govt. Printing Office), 537-560. 1986. Northwestern Atlantic Mesozoic biostratigraphy. In Vogt, P. R., and Tucholke, B. (Eds.), The Geology of North America, Vol. M, The Western North Atlantic Region: Alexandria, VA (Geol. Soc. Am.), 507-525.

1990. Program STRATCOR (Version 1.6) for zonation and correlation of fossil events. Geol. Surv. Can.Rept., 2285 (incl. manual + program diskette).
Gradstein, F. M., and Agterberg, F. P., 1982. Models of Cenozoic foraminiferal stratigraphy, northwestern Atlantic margin. In Cubitt, J. M., and Reyment, R. A. (Eds.), Quantitative Stratigraphic Correlation: Chichester (Wiley), 265-270.

Gradstein, F. M., Agterberg, F. P., Brower, J. C., Schwarzacher, W., 1985. Quantitative Stratigraphy: New York (Reidel and Unesco Publ. Co.). Habib, D., 1972. Dinoflagellate stratigraphy, Leg XI, Deep Sea Drilling Project. In Hollister, C. D., Ewing, J. I., et al., Init. Repts. DSDP, 11: Washington (U.S. Govt. Printing Office), $367-426$.

1977. Comparison of Lower and Middle Cretaceous palynostratigraphic zonations in the western North Atlantic. In Swain, F. M. (Ed.), Stratigraphic Micropaleontology of Atlantic Basin and Borderlands: New York (Elsevier), 341-368.

1979. Palynostratigraphy of Cretaceous sediments from Site 387, western Bermuda Rise. In Tucholke, B. E., and Vogt, P. R., et al., Init. Repts. DSDP, 43: Washington (U.S. Govt. Printing Office), 585-590.

1978. Palynostratigraphy of the Lower Cretaceous section at DSDP Site 391, Blake-Bahama Basin, and its correlation in the North Atlantic. In Benson, W. E., Sheridan, R. E., et al., Init. Repts. DSDP, 44: Washington (U.S. Govt. Printing Office), 887-898.

Habib, D., and Knapp, S., 1982. Stratigraphic utility of Cretaceous small acritarchs. Micropaleontology, 28:335-371.

Habib, D., and Drugg, W. S., 1983. Dinoflagellate age of Middle Jurassic-Early Cretaceous sediments in the Blake-Bahama Basin. In Gradstein, F. M., Sheridan, R. E., et al., Init. Repts. DSDP, 76: Washington (U.S. Govt. Printing Office), 623-638.

1987. Palynology of Sites 603 and 605, Leg 93, Deep Sea Drilling Project. In van Hinte, J. E., Wise, S. W., Jr., et al., Init. Repts. DSDP. 93(Pt. 2): Washington (U.S. Govt. Printing Office), 751-776.

Harland, W. B., Armstrong, R. L., Cox, A. V., Craig, L. E., Smith, A. G., and Smith, D. G., 1990. A Geological Time Scale: Cambridge (Cambridge Univ. Press).

Jansa, L. F., Enos, P., Tucholke, B. E., Gradstein, F. M., and Sheridan, R. E., 1979. Mesozoic-Cenozoic sedimentary formations of the North American Basin; western North Atlantic. In Talwani, M., Hay, W., and Ryan, W.B.F., (Eds.), Deep Drilling Results in the Atlantic Ocean: Continental Margins and Paleoenvironment Washington (Am. Geophys. Union), Maurice Ewing Ser., 3:1-57.

Kent, D. V., and Gradstein, F. M., 1985. A Jurassic and Cretaceous geochronology. Geol. Soc. Am. Bull., 96:1419-1427.

Kuznetsova, K. I., and Seibold, I., 1978. Foraminifers from the Upper Jurassic and Lower Cretaceous of the eastern Atlantic (DSDP Leg 41, Sites 367 and 370). In Lancelot, Y., Seibold, E., et al., Init. Repts. DSDP, 41: Washington (U.S. Govt. Printing Office), 515-538.

Leckie, R. M., 1984. Mid-Cretaceous planktonic foraminiferal biostratigraphy off central Morocco, Deep Sea Drilling Project Leg 79, Sites 545 and 547. In Hinz, K., Winterer, E. L., et al., Init. Repts, DSDP, 79: Washington (U.S. Govt. Printing Office), 579-620.

Lowrie, W., and Ogg, J. G., 1985. A magnetic polarity time scale for Early Cretaceous and Late Jurassic. Earth Planet. Sci. Lett., 76:341-349.

Ludden, J. N., and Gradstein, F. M., et al., 1990. Proc. ODP, Init. Repts., 123: College Station, TX (Ocean Drilling Program).

Luterbacher, H., 1972. Foraminifera from the Lower Cretaceous and Upper Jurassic of the northwestern Atlantic. In Hollister, C. D., Ewing, J. I., et al., Init. Repts. DSDP, 11: Washington (U.S. Govt. Printing Office), 561-594.

McNulty, C. L., 1979. Smaller Cretaceous foraminifers of Leg 43, Deep Sea Drilling Project. In Tucholke, B. E., and Vogt, P. R., et al., Init. Repts. DSDP, 43: Washington (U.S. Govt. Printing Office), 487-506.

Miller, F. X., 1977. The graphic correlation method in biostratigraphy. In Kauffman, E. G., and Hazel, J. E. (Eds.), Concepts and Methods of Biostratigraphy: Strousburg, PA (Hutchinson and Ross), 165-186.

Ogg, J. G., 1983. Magnetostratigraphy of Upper Jurassic and Lowermost Cretaceous sediments, Deep Sea Drilling Project Site 534, western North Atlantic. In Gradstein, F. M., Sheridan, R. E., et al., Init. Repts. DSDP, 76: Washington (U.S. Govt. Printing Office), 685-698.

1987. Early Cretaceous magnetic polarity time scale and the magnetostratigraphy of Deep Sea Drilling Project Sites 603 and 534, western central Atlantic. In van Hinte, J. E., Wise, S. W., Jr., et al., Init. Repts. DSDP, 93 (Pt. 2): Washington (U.S. Govt. Printing Office), $849-880$.

in press. Jurassic magnetic polarity time scale. In Westermann, G.E.G. (Ed)., Circum-Pacific Jurassic: New York (Elsevier). 
Ogg, J. G., and Steiner, M. B., 1988. Late Jurassic and Early Cretaceous magnetic polarity time scale. In Rocha, R. (Ed.), Proc. 2nd Int. Symp. Jurassic Stratigr. (Lisbon, Sept. 1987), 1125-1138.

Okada, H., and Thierstein, H. R., 1979. Calcareous nannoplankton-Leg 43, Deep Sea Drilling Project. In Tucholke, B. E., and Vogt, P. R., et al., Init. Repts. DSDP, 43: Washington (U.S. Govt. Printing Office), 507-574.

Pflaumann, U., and Krasheninnikov, V. A., 1978. Early Cretaceous planktonic foraminifers from eastern North Atlantic, DSDP Leg 41. In Lancelot, Y., Seibold, E., et al., Init. Repts. DSDP, 41: Washington (U.S. Govt. Printing Office), 539-564.

Riley, L. A., and Fenton, J.P.G., 1984. Palynostratigraphy of the Berriasian to Cenomanian sequence at Deep Sea Drilling Project Site 535, Leg 77, southeastern Gulf of Mexico. In Buffler, R. T., Schlager, W., et al., Init. Repts. DSDP, 77: Washington (U.S. Govt. Printing Office), 675-690.

Roth, P. R., 1983. Jurassic and Lower Cretaceous calcareous nannofossils in the western North Atlantic (Site 534): biostratigraphy, preservation, and some observations on biogeography and paleoceanography. In Gradstein, F. M., Sheridan, R. E., et al., Init. Repts. DSDP, 76: Washington (U.S. Govt. Printing Office), 587-622.

Roth, P. R., 1978. Cretaceous nannoplankton biostratigraphy and oceanography of the northwestern Atlantic Ocean. In Benson, W. E., Sheridan, R. E., et al., Init. Repts. DSDP, 44: Washington (U.S. Govt. Printing Office), 731-760.

Schmidt, R. R., 1978. Calcareous nannoplankton from the western North Atlantic, DSDP Leg 44. In Benson, W. E., Sheridan, R. E., et al., Init. Repts. DSDP, 44: Washington (U.S. Govt. Printing Office), 703-730.

Shaw, A. B., 1964. Time in Stratigraphy: New York (McGraw-Hill).

Sigal, J., 1979. Chronostratigraphy and ecostratigraphy of Cretaceous formations recovered on DSDP Leg 47B, Site 398. In Sibuet, J., Ryan, W.B.F., et al., Init. Repts. DSDP, 47 (Pt. 2): Washington (U.S. Govt. Printing Office), 287-326.
Silva, I. P., and McNulty, C. L. 1984. Planktonic foraminifers and calpionellids from Gulf of Mexico sites, Deep Sea Drilling Project Leg 77. In Buffler, R. T., Schlager, W., et al., Init. Repts. DSDP, 77: Washington (U.S. Govt. Printing Office), 547-584.

Sliter, W. V., 1980. Mesozoic foraminifers and deep-sea benthic environments from Deep Sea Drilling Project Sites 415 and 416, eastern North Atlantic. In Lancelot, Y., Winterer, E. L., et al., Init. Repts. DSDP, 50: Washington (U.S. Govt. Printing Office), 353-428.

Sliter, W. V., and Silva, I. P., 1984. Autochthonous and displaced (allochthonous) Cretaceous benthic foraminifers from Deep Sea Drilling Project Leg 77, Sites 535, 536, 537, 538 and 540, Gulf of Mexico. In Buffler, R. T., Schlager, W., et al., Init. Repts. DSDP, 77: Washington (U.S. Govt. Printing Office), 593-629.

Watkins, D. K., and Bowdler, J. L., 1984. Cretaceous nannofossils from Deep Sea Drilling Project Leg 77, southeast Gulf of Mexico. In Buffler, R. T., Schlager, W., et al., Init. Repts. DSDP, 77: Washington (U.S. Govt. Printing Office), 649-674.

Wiegand, G. E., 1984. Cretaceous nannofossils from the northwest African margin, Deep Sea Drilling Project Leg 79. In Hinz, K., Winterer, E. L., et al., Init. Repts. DSDP, 79: Washington (U.S. Govt. Printing Office), 563-579.

Wilcoxon, J. A., 1972. Calcareous nannoplankton ranges, Leg 11, Deep Sea Drilling Project. In Hollister, C. D., Ewing, J. I., et al., Init. Repts. DSDP, 11: Washington (U.S. Govt. Printing Office), 459-474.

Williams, G. L., 1978. Palynological biostratigraphy, Deep Sea Drilling Project Sites 367 and 370. In Talwani, M., Udintsev, G., et al., Init. Repts. DSDP, 38-41 (Supp. Vol. 38, 39, 40, and 41): Washington (U.S. Govt. Printing Office), 779-782.

\section{B-116}

Date of initial receipt: 18 January 1991

Date of acceptance: 2 April 1991 
APPENDIX A

Numerical Dictionary for Stratigraphic Events in 13 DSDP and ODP Sites

\begin{tabular}{|c|c|c|c|}
\hline Number & Name & Number & Name \\
\hline 1 & Caucasella hoterivica FO (PF) & 193 & Lithastrinus floralis $\mathrm{FO}(\mathrm{N})$ \\
\hline 2 & Caucasella hoterivica LO (PF) & 194 & Vagapilla matalosa $\mathrm{FO}(\mathrm{N})$ \\
\hline 7 & Hedbergella planispira FO (PF) & 195 & Conusphaera mexicana LO $(\mathrm{N})$ \\
\hline 8 & Hedbergella trocoidea FO (PF) & 196 & Nannoconus colomii LO (N) \\
\hline 10 & Planomalina buxtorfi LO (PF) & 197 & Nannoconus truitti FO $(\mathrm{N})$ \\
\hline 12 & Rotalipora appenninica FO (PF) & 200 & Chiastozygus striatus FO (N) \\
\hline 13 & Rotalipora appenninica LO (PF) & 202 & Nannoconus bucheri $\mathrm{FO}(\mathrm{N})$ \\
\hline 18 & Ticinella breggiensis FO (PF) & 203 & Parhabdolithus infinitus $\mathrm{FO}(\mathrm{N})$ \\
\hline 19 & Ticinella breggiensis LO (PF) & 204 & Diadorhombus rectus $\mathrm{FO}(\mathrm{N})$ \\
\hline 20 & Ticinella primula $\mathrm{FO}(\mathrm{PF})$ & 206 & Reinharditites fenestratus $\mathrm{FO}(\mathrm{N})$ \\
\hline 21 & Ticinella roberti FO (PF) & 208 & Speetonia colligata $\mathrm{FO}(\mathrm{N})$ \\
\hline 22 & Ticinella roberti LO (PF) & 209 & Prediscosphaera cretacea FO (N) \\
\hline 24 & Hedbergella delrioensis FO (PF) & 210 & Cyclagelosphaera deflandrei (N) FO \\
\hline 26 & Globigerinelloides blowi FO (PF) & 211 & Crucibiscutum salebrosum (N) FO \\
\hline 27 & Globigerinelloides blowi LO (PF) & 212 & Tegumentum striatum (N) FO \\
\hline 29 & Globigerinelloides ferreolensis LO (PF) & 213 & Tegumentum striatum (N) LO \\
\hline 32 & Hedbergella simplex FO (PF) & 214 & Tegumentum tripes (N) FO \\
\hline 36 & Praeglobotruncana delrioensis FO (PF) & 215 & Tegumentum tripes (N) LO \\
\hline 37 & Praeglobotruncana delrioensis LO (PF) & 216 & Eprolithus apertior (N) FO \\
\hline 40 & Hedbergella sigali $\mathrm{FO}(\mathrm{PF})$ & 217 & Eprolithus varoli $(\mathrm{N}) \mathrm{FO}$ \\
\hline 41 & Hedbergella sigali LO (PF) & 218 & Flabellites biforaminis (N) FO \\
\hline 55 & Dorothia praehauteriviana FO (BF) & 219 & Corolithion achylosus (N) FO \\
\hline 56 & Epistomina uhligi LO (BF) & 220 & Hayesites irregularis (N) FO \\
\hline 57 & Epistomina caracolla LO (BF) & 221 & Prediscosphaera columnata $(\mathrm{N})$ FO \\
\hline 60 & Gavelinella barremiana LO (BF) & 251 & Biorbifera johnewingii $\mathrm{FO}(\mathrm{P})$ \\
\hline 67 & Haplophragmium inconstans FO (BF) & 253 & Druggidium apicopaucicum FO (P) \\
\hline 68 & Haplophragmium inconstans LO (BF) & 254 & Druggidium apicopaucicum LO (P) \\
\hline 70 & Lenticulina busnardoi FO (BF) & 255 & Druggidium deflandrei $\mathrm{FO}(\mathrm{P})$ \\
\hline 71 & Lenticulina busnardoi LO (BF) & 256 & Druggidium deflandrei $\mathrm{LO}(\mathrm{P})$ \\
\hline 72 & Lenticulina crepidularis LO (BF) & 257 & Druggidium rhabdoreticulatum $\mathrm{FO}(\mathrm{P})$ \\
\hline 74 & Lenticulina nodosa $\mathrm{FO}$ (BF) & 259 & Odontochitina operculata $\mathrm{FO}(\mathrm{P})$ \\
\hline 76 & Lenticulina ouachensis LO (BF) & 261 & Phoberocysta neocomica LO (P) \\
\hline 78 & Lenticulina quenstedti LO (BF) & 262 & Scriniodinium dictyotum $\mathrm{LO}(\mathrm{P})$ \\
\hline 87 & Trochammina quinqueloba $\mathrm{FO}(\mathrm{BF})$ & 263 & Spinidinium echinoideum $\mathrm{FO}(\mathrm{P})$ \\
\hline 88 & Trochammina quinqueloba LO (BF) & 264 & Subtilisphaera perlucida LO (P) \\
\hline 89 & Verneuilinoides neocomiensis LO (BF) & 266 & Spinidinium vestitum $\mathrm{FO}(\mathrm{P})$ \\
\hline 90 & Verneuilinoides neocomiensis FO (BF) & 267 & Diconodinium davidii $(\mathrm{P}) \mathrm{FO}$ \\
\hline 91 & Pseudoreophax cisovnicensis FO (BF) & 268 & Diconodinium davidii (P) LO \\
\hline 92 & Paalzowella feifeli LO (BF) & 269 & Pseudoceratium turneri (P) FO \\
\hline 93 & Epistomina caracolla $\mathrm{P}(\mathrm{BF})$ & 270 & Dingodinium cerviculum (P) LO \\
\hline 94 & Gavelinella bettenstaedti $\mathrm{P}$ (BF) & 271 & Rhombodella paucispina (P) LO \\
\hline 95 & Hormosina cf. crassa FO (BF) & 272 & Ascodinium sp. A (P) PEAK \\
\hline 96 & Dorothia praehauteriviana LO (BF) & 273 & Muderongia australis (P) FO \\
\hline 97 & Gavelinella barremiana FO (BF) & 274 & Batioladinium reticulatum $(\mathrm{P}) \mathrm{P}$ \\
\hline 98 & Conorboides hofkeri FO (BF) & 275 & Dissimulidinium ibispinosum (P) LO \\
\hline 100 & Lenticulina ouachensis FO (BF) & 276 & Egmontodinium torynum $(\mathrm{P}) \mathrm{P}$ \\
\hline 101 & Epistomina caracolla FO (BF) & 301 & MOr top (M) \\
\hline 154 & Cruciellipsis cuvillieri FO (N) & 303 & Mln top (M) \\
\hline 155 & Cruciellipsis cuvillieri LO (N) & 304 & M1r top (M) \\
\hline 156 & Cyclagelosphaera deflandrei $\mathrm{LO}(\mathrm{N})$ & 305 & $\mathrm{M} 2 \mathrm{n}$ top $(\mathrm{M})$ \\
\hline 157 & Chiastozygus litterarius FO (N) & 307 & $\mathrm{M} 3 \mathrm{r}$ top $(\mathrm{M})$ \\
\hline 158 & Conusphaera mexicana FO (N) & 309 & $\mathrm{M} 4 \mathrm{n}$ top $(\mathrm{M})$ \\
\hline 159 & Calcicalathina oblongata $\mathrm{FO}(\mathrm{N})$ & 311 & M5r top (M) \\
\hline 160 & Calcicalathina oblongata LO (N) & 315 & $\mathrm{M} 7 \mathrm{n}$ top $(\mathrm{M})$ \\
\hline 163 & Diadorhombus rectus LO $(\mathrm{N})$ & 316 & M7r top (M) \\
\hline 164 & Eiffellithus eximius $\mathrm{FO}(\mathrm{N})$ & 317 & $\mathrm{M} 8 \mathrm{n}$ top $(\mathrm{M})$ \\
\hline 165 & Eiffellithus turriseiffeli $\mathrm{FO}(\mathrm{N})$ & 318 & $\mathrm{M} 8 \mathrm{r}$ top $(\mathrm{M})$ \\
\hline 171 & Lithraphidites carniolensis FO (N) & 319 & M9n top (M) \\
\hline 173 & Nannoconus colomi FO $(\mathrm{N})$ & 321 & M10n top (M) \\
\hline 176 & Rhagodiscus angustus FO (N) & 322 & M10r top (M) \\
\hline 180 & Rucinolithus irregularis FO (N) & 323 & M10Nn top (M) \\
\hline 184 & Rucinolithus wisei FO (N) & 324 & M10Nr top (M) \\
\hline 185 & Rucinolithus wisei $\mathrm{LO}(\mathrm{N})$ & 325 & M1ln top (M) \\
\hline 186 & Stephanolithion bigotii LO (N) & 338 & M15r top (M) \\
\hline 187 & Speetonia colligata LO $(\mathrm{N})$ & 339 & M16n top (M) \\
\hline 188 & Tubodiscus verenae FO (N) & 340 & M16r top (M) \\
\hline 189 & Tubodiscus verenae LO $(\mathrm{N})$ & \multirow{2}{*}{\multicolumn{2}{|c|}{ Number of entries printed: 135}} \\
\hline 190 & Vagapilla stradneri $\mathrm{FO}(\mathrm{N})$ & & \\
\hline
\end{tabular}


APPENDIX B

Listing of all Microfossil and Geomagnetic Polarity Events in 10 Atlantic and 3 Indian Ocean Sites (used here)

\begin{tabular}{|c|c|c|}
\hline Depth & Number & Fossil Name \\
\hline \multirow[t]{2}{*}{00774.} & 36 & Praeglobotruncana delrioensis FO (PF) \\
\hline & 24 & Hedbergella delrioensis FO (PF) \\
\hline 00793. & 263 & Spinidinium echinoideum $\mathrm{FO}(\mathrm{P})$ \\
\hline 00831 . & 191 & Tranolithus orionatus $\mathrm{FO}(\mathrm{N})$ \\
\hline \multirow[t]{2}{*}{00863.} & 266 & Spinidinium vestitum $\mathrm{FO}(\mathrm{P})$ \\
\hline & 264 & Subtilisphaera perlucida LO (P) \\
\hline 00908. & 256 & Druggidium deflandrei $\mathrm{LO}(\mathrm{P})$ \\
\hline 00923. & 41 & Hedbergella sigali LO (PF) \\
\hline 00941. & 7 & Hedbergella planispira $\mathrm{FO}(\mathrm{PF})$ \\
\hline 00956. & 304 & M1r top (M) \\
\hline 00965. & 195 & Conusphaera mexicana LO (N) \\
\hline 00968. & 261 & Phoberocysta neocomica LO (P) \\
\hline 00973. & 40 & Hedbergella sigali FO (PF) \\
\hline 00983. & 309 & M4n top (M) \\
\hline 00991. & 160 & Calcicalathina oblongata LO (N) \\
\hline 01008. & 311 & M5r top (M) \\
\hline 01018. & 187 & Speetonia colligata $\mathrm{LO}(\mathrm{N})$ \\
\hline 01028. & 315 & M7n top (M) \\
\hline 01056. & 316 & $\mathrm{M} 7 \mathrm{r}$ top $(\mathrm{M})$ \\
\hline 01057. & 155 & Cruciellipsis cuvillieri LO (N) \\
\hline 01073. & 317 & M8n top (M) \\
\hline \multirow[t]{2}{*}{01074.} & 259 & Odontochitina operculata $\mathrm{FO}(\mathrm{P})$ \\
\hline & 200 & Chiastozygus striatus $\mathrm{FO}(\mathrm{N})$ \\
\hline 01090. & 318 & M8r top (M) \\
\hline 01099. & 257 & Druggidium rhabdoreticulatum FO (P) \\
\hline 01112. & 321 & M10n top (M) \\
\hline 01125. & 322 & Mior top (M) \\
\hline 01127. & 189 & Tubodiscus verenae $\mathrm{LO}(\mathrm{N})$ \\
\hline 01128. & 323 & M10Nn top (M) \\
\hline 01130. & 156 & Cyclagelosphaera deflandrei $\mathrm{LO}(\mathrm{N})$ \\
\hline 01138. & 202 & Nannoconus bucheri $\mathrm{FO}(\mathrm{N})$ \\
\hline 01143. & 163 & Diadorhombus rectus LO $(\mathrm{N})$ \\
\hline 01149. & 88 & Trochammina quinqueloba LO (BF) \\
\hline \multirow[t]{2}{*}{01167.} & 74 & Lenticulina nodosa FO (BF) \\
\hline & 55 & Dorothia praehauteriviana FO (BF) \\
\hline 01168. & 324 & M10Nr top $(\mathrm{M})$ \\
\hline 01172. & 325 & M1 ln top (M) \\
\hline 01189. & 203 & Parhabdolithus infinitus $\mathrm{FO}(\mathrm{N})$ \\
\hline 01193. & 262 & Scriniodinium dictyotum LO (P) \\
\hline 01205. & 255 & Druggidium deflandrei $\mathrm{FO}(\mathrm{P})$ \\
\hline 01207. & 204 & Diadorhombus rectus FO (N) \\
\hline 01223. & 185 & Rucinolithus wisei LO (N) \\
\hline \multirow[t]{2}{*}{01230.} & 188 & Tubodiscus verenae $\mathrm{FO}(\mathrm{N})$ \\
\hline & 159 & Calcicalathina oblongata $\mathrm{FO}(\mathrm{N})$ \\
\hline 01243. & 253 & Druggidium apicopaucicum FO (P) \\
\hline 01253. & 338 & MI5r top (M) \\
\hline 01264. & 339 & M16n top (M) \\
\hline \multirow[t]{2}{*}{01269.} & 340 & M1 $6 r$ top (M) \\
\hline & 206 & Reinharditites fenestratus FO (N) \\
\hline 01272. & 208 & Speetonia colligata $\mathrm{FO}(\mathrm{N})$ \\
\hline 01287. & 251 & Biorbifera johnewingii FO (P) \\
\hline 01288. & 190 & Vagapilla stradneri $\mathrm{FO}(\mathrm{N})$ \\
\hline 01331. & 184 & Rucinolithus wisei $\mathrm{FO}(\mathrm{N})$ \\
\hline 01332. & 68 & Haplophragmium inconstans LO (BF) \\
\hline 01340 & 173 & Nannoconus colomi $\mathrm{FO}(\mathrm{N})$ \\
\hline 01350 & 186 & Stephanolithion bigotii LO (N) \\
\hline 01352. & 67 & Haplophragmium inconstans FO (BF) \\
\hline 01353. & 171 & Lithraphidites carniolensis FO (N) \\
\hline 01359. & 154 & Cruciellipsis cuvillieri $\mathrm{FO}(\mathrm{N})$ \\
\hline 01363. & 78 & Lenticulina quenstedti LO (BF) \\
\hline 01411. & 158 & Conusphaera mexicana $\mathrm{FO}(\mathrm{N})$ \\
\hline 01446. & 87 & Trochammina quinqueloba $\mathrm{FO}(\mathrm{BF})$ \\
\hline
\end{tabular}

\begin{tabular}{|c|c|c|}
\hline \multicolumn{3}{|c|}{ 2. DSDP Leg 93, Hole 603B, Western Atlantic Ocean. } \\
\hline Depth & Number & Fossil Name \\
\hline 01307. & 311 & M5r top (M) \\
\hline 01320. & 160 & Calcicalathina oblongata LO (N) \\
\hline 01324 & 157 & Chiastozygus litterarius $\mathrm{FO}(\mathrm{N})$ \\
\hline 01330 & 187 & Speetonia colligata LO $(\mathrm{N})$ \\
\hline 01332. & 315 & M7n top (M) \\
\hline 01347. & 254 & Druggidium apicopaucicum LO (P) \\
\hline 01360. & 155 & Cruciellipsis cuvillieri LO (N) \\
\hline 01363. & 316 & $\mathrm{M} 7 \mathrm{r}$ top $(\mathrm{M})$ \\
\hline 01373. & 259 & Odontochitina operculata $\mathrm{FO}(\mathrm{P})$ \\
\hline 01381. & 317 & M8n top (M) \\
\hline 01384. & 318 & M8r top (M) \\
\hline 01387. & 40 & Hedbergella sigali $\mathrm{FO}(\mathrm{PF})$ \\
\hline 01404. & 257 & Druggidium rhabdoreticulatum $\mathrm{FO}(\mathrm{P})$ \\
\hline 01423. & 321 & M10n top (M) \\
\hline 01427. & 156 & Cyclagelosphaera deflandrei $\mathrm{LO}(\mathrm{N})$ \\
\hline 01433. & 322 & M10r top (M) \\
\hline 01436. & 163 & Diadorhombus rectus LO (N) \\
\hline 01446. & 189 & Tubodiscus verenae $\mathrm{LO}(\mathrm{N})$ \\
\hline 01447. & 323 & M10Nn top (M) \\
\hline 01469. & 1 & Caucasella hoterivica FO (PF) \\
\hline 01476. & 262 & Scriniodinium dictyotum $\mathrm{LO}(\mathrm{P})$ \\
\hline 01483. & 324 & M10Nr top (M) \\
\hline 01493. & 325 & MIIn top $(\mathrm{M})$ \\
\hline \multirow[t]{2}{*}{01509.} & 71 & Lenticulina busnardoi LO (BF) \\
\hline & 55 & Dorothia praehauteriviana $\mathrm{FO}(\mathrm{BF})$ \\
\hline 01518. & 255 & Druggidium deflandrei $\mathrm{FO}(\mathrm{P})$ \\
\hline 01526. & 159 & Calcicalathina oblongata $\mathrm{FO}(\mathrm{N})$ \\
\hline 01546. & 185 & Rucinolithus wisei LO (N) \\
\hline 01549. & 253 & Druggidium apicopaucicum $\mathrm{FO}(\mathrm{P})$ \\
\hline 01554. & 338 & M15r top (M) \\
\hline 01556. & 188 & Tubodiscus verenae $\mathrm{FO}(\mathrm{N})$ \\
\hline 01559 & 339 & M16n top (M) \\
\hline 01565 & 204 & Diadorhombus rectus $\mathrm{FO}(\mathrm{N})$ \\
\hline 01570. & 208 & Speetonia colligata $\mathrm{FO}(\mathrm{N})$ \\
\hline 01572. & 340 & M16r top (M) \\
\hline 01574. & 251 & Biorbifera johnewingii $\mathrm{FO}(\mathrm{P})$ \\
\hline
\end{tabular}

3. DSDP Leg 44, Hole 391C, Western North Atlantic Ocean.

\begin{tabular}{|c|c|c|}
\hline Depth & Number & Fossil Name \\
\hline 00784. & 266 & Spinidinium vestitum $\mathrm{FO}(\mathrm{P})$ \\
\hline 00926. & 256 & Druggidium deflandrei LO (P) \\
\hline 00927. & 8 & Hedbergella trocoidea FO (PF) \\
\hline \multirow[t]{2}{*}{00963.} & 195 & Conusphaera mexicana LO (N) \\
\hline & 176 & Rhagodiscus angustus $\mathrm{FO}(\mathrm{N})$ \\
\hline 01009. & 60 & Gavelinella barremiana LO (BF) \\
\hline 01010. & 196 & Nannoconus colomii LO (N) \\
\hline 01012. & 254 & Druggidium apicopaucicum LO (P) \\
\hline \multirow[t]{2}{*}{01019.} & 157 & Chiastozygus litterarius FO $(\mathrm{N})$ \\
\hline & 194 & Vagapilla matalosa $\mathrm{FO}(\mathrm{N})$ \\
\hline 01030. & 160 & Calcicalathina oblongata LO (N) \\
\hline 01031. & 155 & Cruciellipsis cuvillieri LO (N) \\
\hline 01091. & 259 & Odontochitina operculata FO (P) \\
\hline 01105 . & 197 & Nannoconus truitti $\mathrm{FO}(\mathrm{N})$ \\
\hline 01126. & 156 & Cyclagelosphaera deflandrei LO (N) \\
\hline 01131. & 257 & Druggidium rhabdoreticulatum $\mathrm{FO}(\mathrm{P})$ \\
\hline 01137. & 189 & Tubodiscus verenae $\mathrm{LO}(\mathrm{N})$ \\
\hline \multirow[t]{2}{*}{01147.} & 55 & Dorothia praehauteriviana $\mathrm{FO}(\mathrm{BF})$ \\
\hline & 74 & Lenticulina nodosa FO (BF) \\
\hline 01170. & 202 & Nannoconus bucheri FO $(\mathrm{N})$ \\
\hline 01177. & 255 & Druggidium deflandrei $\mathrm{FO}(\mathrm{P})$ \\
\hline 01178. & 185 & Rucinolithus wisei LO (N) \\
\hline \multirow[t]{2}{*}{01198.} & 188 & Tubodiscus verenae $\mathrm{FO}(\mathrm{N})$ \\
\hline & 203 & Parhabdolithus infinitus FO (N) \\
\hline 01199. & 204 & Diadorhombus rectus $\mathrm{FO}(\mathrm{N})$ \\
\hline \multirow[t]{2}{*}{01210.} & 159 & Calcicalathina oblongata FO (N) \\
\hline & 206 & Reinharditites fenestratus $\mathrm{FO}(\mathrm{N})$ \\
\hline 01212. & 253 & Druggidium apicopaucicum $\mathrm{FO}(\mathrm{P})$ \\
\hline 01229. & 190 & Vagapilla stradneri $\mathrm{FO}(\mathrm{N})$ \\
\hline 01238. & 184 & Rucinolithus wisei $\mathrm{FO}(\mathrm{N})$ \\
\hline 01263. & 251 & Biorbifera johnewingii $\mathrm{FO}(\mathrm{P})$ \\
\hline 01312. & 171 & Lithraphidites carniolensis $\mathrm{FO}(\mathrm{N})$ \\
\hline 01321. & 173 & Nannoconus colomi $\mathrm{FO}(\mathrm{N})$ \\
\hline 01372. & 154 & Cruciellipsis cuvillieri FO (N) \\
\hline
\end{tabular}


APPENDIX B (continued).

\begin{tabular}{|c|c|c|}
\hline \multicolumn{3}{|c|}{ 4. DSDP Leg 11, Site 105, Western Atlantic Ocean. } \\
\hline Depth & Number & Fossil Name \\
\hline 00306. & 10 & Planomalina buxtorfi LO (PF) \\
\hline 00307. & 13 & Rotalipora appenninica LO (PF) \\
\hline 00309. & 263 & Spinidinium echinoideum $\mathrm{FO}(\mathrm{P})$ \\
\hline 00317. & 12 & Rotalipora appenninica FO (PF) \\
\hline 00322 . & 165 & Eiffellithus turriseiffeli $\mathrm{FO}(\mathrm{N})$ \\
\hline 00388. & 266 & Spinidinium vestitum $\mathrm{FO}(\mathrm{P})$ \\
\hline 00392. & 264 & Subtilisphaera perlucida LO (P) \\
\hline 00404 . & 256 & Druggidium deflandrei $\mathrm{LO}(\mathrm{P})$ \\
\hline 00426. & 254 & Druggidium apicopaucicum LO (P) \\
\hline 00430. & 155 & Cruciellipsis cuvillieri $\mathrm{LO}(\mathrm{N})$ \\
\hline 00433. & 259 & Odontochitina operculata $\mathrm{FO}(\mathrm{P})$ \\
\hline 00440 . & 257 & Druggidium rhabdoreticulatum $\mathrm{FO}(\mathrm{P})$ \\
\hline 00457. & 55 & Dorothia praehauteriviana $\mathrm{FO}(\mathrm{BF})$ \\
\hline 00459. & 262 & Scriniodinium dictyotum LO (P) \\
\hline 00469. & 74 & Lent icul ina nodosa FO ( BF) \\
\hline 00484 . & 255 & Druggidium deflandrei $\mathrm{FO}(\mathrm{P})$ \\
\hline 00504 . & 253 & Druggidium apicopaucicum $\mathrm{FO}(\mathrm{P})$ \\
\hline 00533. & 251 & Biorbifera johnewing ii $\mathrm{FO}(\mathrm{P})$ \\
\hline 00585 . & 186 & Stephanolithion bigotii $\mathrm{LO}(\mathrm{N})$ \\
\hline 00603. & 154 & Cruciellipsis cuvillieri $\mathrm{FO}(\mathrm{N})$ \\
\hline
\end{tabular}

5. DSDP Leg 41, Site 370, Eastern Atlantic Ocean.

\begin{tabular}{|c|c|c|}
\hline Depth & Number & Fossil Name \\
\hline \multirow[t]{3}{*}{00674.} & 13 & Rotalipora appenninica LO (PF) \\
\hline & 19 & Ticinella breggiensis LO (PF) \\
\hline & 37 & Praeglobotruncana delrioensis $\mathrm{LO}(\mathrm{PF})$ \\
\hline \multirow[t]{3}{*}{00721.} & 32 & Hedbergella simplex $\mathrm{FO}(\mathrm{PF})$ \\
\hline & 18 & Ticinella breggiensis FO (PF) \\
\hline & 12 & Rotalipora appenninica FO (PF) \\
\hline 00733. & 165 & Eiffellithus turriseiffeli $\mathrm{FO}(\mathrm{N})$ \\
\hline 00740. & 36 & Praeglobotruncana delrioensis FO (PF) \\
\hline \multirow[t]{2}{*}{00816 . } & 20 & Ticinella primula $\mathrm{FO}(\mathrm{PF})$ \\
\hline & 8 & Hedbergella trocoidea $\mathrm{FO}(\mathrm{PF})$ \\
\hline 00827. & 264 & Subtilisphaera perlucida LO (P) \\
\hline \multirow[t]{2}{*}{00828.} & 7 & Hedbergella planispira $\mathrm{FO}(\mathrm{PF})$ \\
\hline & 27 & Globigerinelloides blowi LO (PF) \\
\hline \multirow[t]{2}{*}{00829.} & 176 & Rhagodiscus angustus $\mathrm{FO}(\mathrm{N})$ \\
\hline & 193 & Lithastrinus floralis $\mathrm{FO}(\mathrm{N})$ \\
\hline \multirow[t]{2}{*}{00840.} & 196 & Nannoconus colomii LO (N) \\
\hline & 26 & Globigerinelloides blowi $\mathrm{FO}$ (PF) \\
\hline 00876. & 60 & Gavelinella barremiana LO (BF) \\
\hline 00885. & 259 & Odontochitina operculata $\mathrm{FO}(\mathrm{P})$ \\
\hline 00889. & 2 & Caucasella hoterivica LO (PF) \\
\hline 00891. & 155 & Cruciellipsis cuvillieri LO (N) \\
\hline 01120. & 55 & Dorothia praehauteriviana $\mathrm{FO}(\mathrm{BF})$ \\
\hline 01129. & 74 & Lenticulina nodosa FO (BF) \\
\hline 01139. & 71 & Lenticulina busnardoi LO (BF) \\
\hline 01140. & 188 & Tubodiscus verenae $\mathrm{FO}(\mathrm{N})$ \\
\hline 01158. & 159 & Calcicalathina oblongata $\mathrm{FO}(\mathrm{N})$ \\
\hline 01176. & 190 & Vagapilla stradneri $\mathrm{FO}(\mathrm{N})$ \\
\hline
\end{tabular}

6. DSDP Leg 77, Hole 535A, Western North Atlantic Ocean.

Depth Number Fossil Name

\begin{tabular}{|c|c|c|}
\hline 00160. & 10 & Planomalina buxtorfi LO (PF) \\
\hline 00326. & 20 & Ticinella primula $\mathrm{FO}(\mathrm{PF})$ \\
\hline 00368. & 7 & Hedbergella planispira FO (PF) \\
\hline 00401. & 21 & Ticinella roberti $\mathrm{FO}(\mathrm{PF})$ \\
\hline 00402. & 261 & Phoberocysta neocomica LO (P) \\
\hline 00403. & 195 & Conusphaera mexicana LO $(\mathrm{N})$ \\
\hline 00404. & 8 & Hedbergella trocoidea FO (PF) \\
\hline 00421. & 259 & Odontochitina operculata FO (P) \\
\hline 00422. & 157 & Chiastozygus litterarius $\mathrm{FO}(\mathrm{N})$ \\
\hline 00444. & 155 & Cruciellipsis cuvillieri LO (N) \\
\hline 00459. & 187 & Speetonia colligata LO $(\mathrm{N})$ \\
\hline 00478. & 257 & Druggidium rhabdoreticulatum $\mathrm{FO}(\mathrm{P})$ \\
\hline 00521. & 200 & Chiastozygus striatus $\mathrm{FO}(\mathrm{N})$ \\
\hline 00531. & 189 & Tubodiscus verenae $\mathrm{LO}(\mathrm{N})$ \\
\hline 00576. & 163 & Diadorhombus rectus LO (N) \\
\hline 00611 . & 203 & Parhabdolithus infinitus FO (N) \\
\hline 00648. & 188 & Tubodiscus verenae $\mathrm{FO}(\mathrm{N})$ \\
\hline 00660. & 71 & Lenticulina busnardoi LO (BF) \\
\hline 00675. & 206 & Reinharditites fenestratus FO (N) \\
\hline 00684. & 253 & Druggidium apicopaucicum FO (P) \\
\hline
\end{tabular}

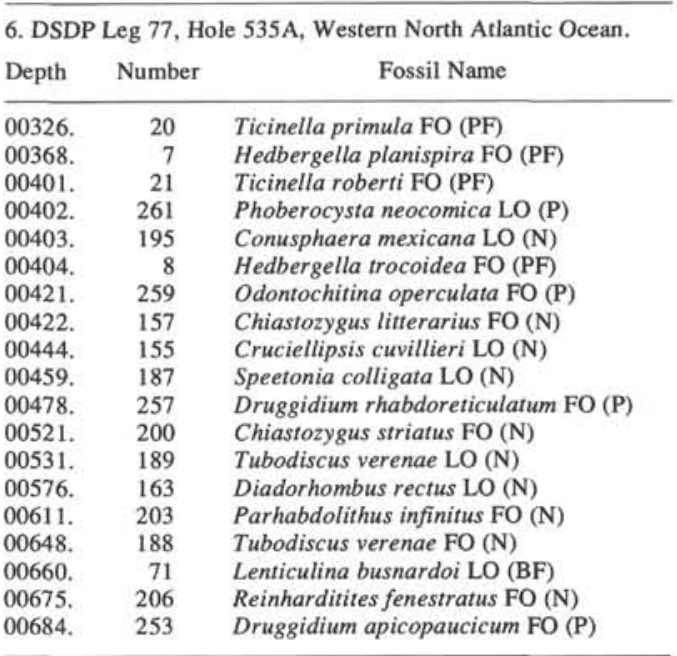

7. DSDP Leg 50, Hole 416A, Eastern Atlantic Ocean.

Depth Number Fossil Name

\begin{tabular}{|c|c|c|}
\hline 00730. & 24 & Hedbergella delrioensis FO (PF) \\
\hline 00764. & 176 & Rhagodiscus angustus FO (N) \\
\hline 00855. & 7 & Hedbergella planispira $\mathrm{FO}(\mathrm{PF})$ \\
\hline 00897. & 157 & Chiastozygus litterarius FO (N) \\
\hline 00900. & 76 & Lenticulina ouachensis LO (BF) \\
\hline 00982. & 155 & Cruciellipsis cuvillieri LO (N) \\
\hline \multirow[t]{2}{*}{01118.} & 57 & Epistomina caracolla LO (BF) \\
\hline & 96 & Dorothia praehauteriviana LO (BF) \\
\hline 01188. & 189 & Tubodiscus verenae $\mathrm{LO}(\mathrm{N})$ \\
\hline 01198. & 88 & Trochammina quinqueloba LO (BF) \\
\hline 01199. & 163 & Diadorhombus rectus LO $(\mathrm{N})$ \\
\hline 01204. & 97 & Gavelinella barremiana $\mathrm{FO}$ (BF) \\
\hline 01222. & 71 & Lenticulina busnardoi LO (BF) \\
\hline 01303. & 74 & Lenticulina nodosa FO (BF) \\
\hline 01361. & 101 & Epistomina caracolla $\mathrm{FO}(\mathrm{BF})$ \\
\hline 01391. & 185 & Rucinolithus wisei LO (N) \\
\hline 01400 . & 55 & Dorothia praehauteriviana FO (BF) \\
\hline 01417. & 100 & Lenticulina ouachensis FO (BF) \\
\hline 01459. & 70 & Lenticulina busnardoi FO (BF) \\
\hline \multirow[t]{2}{*}{01531.} & 188 & Tubodiscus verenae $\mathrm{FO}(\mathrm{N})$ \\
\hline & 159 & Calcicalathina oblongata $\mathrm{FO}(\mathrm{N})$ \\
\hline 01559. & 171 & Lithraphidites carniolensis $\mathrm{FO}(\mathrm{N})$ \\
\hline 01560. & 184 & Rucinolithus wisei $\mathrm{FO}(\mathrm{N})$ \\
\hline 01569. & 56 & Epistomina uhligi LO (BF) \\
\hline 01572. & 173 & Nannoconus colomi $\mathrm{FO}(\mathrm{N})$ \\
\hline 01615. & 154 & Cruciellipsis cuvillieri $\mathrm{FO}(\mathrm{N})$ \\
\hline 01616. & 67 & Haplophragmium inconstans $\mathrm{FO}$ (BF) \\
\hline 01624. & 158 & Conusphaera mexicana $\mathrm{FO}(\mathrm{N})$ \\
\hline
\end{tabular}

8. DSDP Leg 48A, Hole 398D, Eastern Atlantic Ocean.

Depth Number Fossil Name

\begin{tabular}{lrl}
\hline 00887. & 164 & Eiffellithus eximius FO (N) \\
00984. & 22 & Ticinella roberti LO (PF) \\
00993. & 165 & Eiffellithus turriseiffeli FO (N) \\
01250. & 20 & Ticinella primula FO (PF) \\
01311. & 209 & Prediscosphaera cretacea FO (N) \\
01345. & 7 & Hedbergella planispira FO (PF) \\
01468. & 8 & Hedbergella trocoidea FO (PF) \\
01487. & 176 & Rhagodiscus angustus FO (N) \\
01571. & 193 & Lithastrinus floralis FO (N) \\
01573. & 196 & Nannoconus colomii LO (N) \\
01591. & 60 & Gavelinella barremiana LO (BF) \\
01592. & 157 & Chiastozygus litterarius FO (N) \\
01598. & 180 & Rucinolithus irregularis FO (N) \\
01626. & 160 & Calcicalathina oblongata LO (N) \\
01697. & 197 & Nannoconus truitti FO (N) \\
01706. & 194 & Vagapilla matalosa FO (N) \\
01716. & 155 & Cruciellipsis cuvillieri LO (N)
\end{tabular}


APPENDIX B (continued).

\begin{tabular}{|c|c|c|}
\hline Depth & Number & Fossil Name \\
\hline 00701. & $\begin{array}{r}36 \\
8\end{array}$ & $\begin{array}{l}\text { Praeglobotruncana delrioensis } \mathrm{FO}(\mathrm{PF}) \\
\text { Hedbergella trocoidea } \mathrm{FO}(\mathrm{PF})\end{array}$ \\
\hline 00727. & 165 & Eiffellithus turriseiffeli $\mathrm{FO}(\mathrm{N})$ \\
\hline 00730. & $\begin{array}{l}20 \\
24\end{array}$ & $\begin{array}{l}\text { Ticinella primula } \mathrm{FO}(\mathrm{PF}) \\
\text { Hedbergella delrioensis } \mathrm{FO}(\mathrm{PF})\end{array}$ \\
\hline 00787. & 7 & Hedbergella planispira FO (PF) \\
\hline 00891. & $\begin{array}{l}157 \\
193\end{array}$ & $\begin{array}{l}\text { Chiastozygus litterarius } \mathrm{FO}(\mathrm{N}) \\
\text { Lithastrinus floralis } \mathrm{FO}(\mathrm{N})\end{array}$ \\
\hline 00897. & 196 & Nannoconus colomii $\mathrm{LO}(\mathrm{N})$ \\
\hline 00916. & 160 & Calcicalathina oblongata LO (N) \\
\hline 00940. & 155 & Cruciellipsis cuvillieri LO (N) \\
\hline 00941. & 203 & Parhabdolithus infinitus FO (N) \\
\hline 01024. & 185 & Rucinolithus wisei LO (N) \\
\hline & 204 & Diadorhombus rectus FO (N) \\
\hline 01083. & 184 & Rucinolithus wisei $\mathrm{FO}(\mathrm{N})$ \\
\hline 01085. & 171 & Lithraphidites carniolensis FO (N) \\
\hline & 173 & Nannoconus colomi $\mathrm{FO}(\mathrm{N})$ \\
\hline 01087. & 154 & Cruciellipsis cuvillieri FO (N) \\
\hline
\end{tabular}

10. DSDP Leg 43, Site 387, Western Atlantic Ocean.

\begin{tabular}{|c|c|c|}
\hline Depth & Number & Fossil Name \\
\hline 00469. & 165 & Eiffellithus turriseiffeli $\mathrm{FO}(\mathrm{N})$ \\
\hline 00471. & 209 & Prediscosphaera cretacea $\mathrm{FO}(\mathrm{N})$ \\
\hline 00565. & 256 & Druggidium deflandrei $\mathrm{LO}(\mathrm{P})$ \\
\hline 00603. & 195 & Conusphaera mexicana LO $(\mathrm{N})$ \\
\hline 00632. & 160 & Calcicalathina oblongata LO (N) \\
\hline \multirow[t]{2}{*}{00633.} & 259 & Odontochitina operculata $\mathrm{FO}(\mathrm{P})$ \\
\hline & 155 & Cruciellipsis cuvillieri LO (N) \\
\hline 00642. & 156 & Cyclagelosphaera deflandrei $\mathrm{LO}(\mathrm{N})$ \\
\hline 00660. & 257 & Druggidium rhabdoreticulatum $\mathrm{FO}(\mathrm{P})$ \\
\hline 00735 . & 255 & Druggidium deflandrei $\mathrm{FO}(\mathrm{P})$ \\
\hline \multirow[t]{2}{*}{00746.} & 204 & Diadorhombus rectus $\mathrm{FO}(\mathrm{N})$ \\
\hline & 185 & Rucinolithus wisei LO (N) \\
\hline 00765. & 159 & Calcicalathina oblongata $\mathrm{FO}(\mathrm{N})$ \\
\hline 00772. & 253 & Druggidium apicopaucicum $\mathrm{FO}(\mathrm{P})$ \\
\hline 00773. & 188 & Tubodiscus verenae $\mathrm{FO}(\mathrm{N})$ \\
\hline 00788. & 190 & Vagapilla stradneri $\mathrm{FO}(\mathrm{N})$ \\
\hline 00790. & 251 & Biorbifera johnewingii $\mathrm{FO}(\mathrm{P})$ \\
\hline
\end{tabular}

11. ODP Leg 123, Hole 765C, Eastern Indian Ocean.

Depth Number Fossil Name

\begin{tabular}{|c|c|c|}
\hline 00655. & 267 & Diconodinium davidii (P) FO \\
\hline \multirow[t]{2}{*}{00665.} & 270 & Dingodinium cerviculum $(\mathrm{P})$ LO \\
\hline & 271 & Rhombodella paucispina (P) LO \\
\hline 00683. & 268 & Diconodinium davidii (P) LO \\
\hline 00685. & 221 & Prediscosphaera columnata $(\mathrm{N}) \mathrm{FO}$ \\
\hline 00703. & 29 & Globigerinelloides ferreolensis LO \\
\hline 00712. & 7 & Hedbergella planispira FO (PF) \\
\hline 00717. & 220 & Hayesites irregularis (N) FO \\
\hline \multirow[t]{4}{*}{00721.} & 269 & Pseudoceratium turneri $(\mathrm{P}) \mathrm{FO}$ \\
\hline & 272 & Ascodinium sp. A (P) PEAK \\
\hline & 24 & Hedbergella delrioensis $\mathrm{FO}(\mathrm{PF})$ \\
\hline & 219 & Corolithion achylosus (N) FO \\
\hline 00724. & 157 & Chiastozygus litterarius $\mathrm{FO}(\mathrm{N})$ \\
\hline \multirow[t]{4}{*}{00726.} & 216 & Eprolithus apertior (N) FO \\
\hline & 217 & Eprolithus varoli $(\mathrm{N}) \mathrm{FO}$ \\
\hline & 218 & Flabellites biforaminis $(\mathrm{N}) \mathrm{FO}$ \\
\hline & 176 & Rhagodiscus angustus $\mathrm{FO}(\mathrm{N})$ \\
\hline 00788. & 301 & M0r top (M) \\
\hline 00794. & 303 & Mln top (M) \\
\hline 00816. & 259 & Odontochitina operculata FO (P) \\
\hline 00833. & 307 & $\mathrm{M} 3 \mathrm{r}$ top $(\mathrm{M})$ \\
\hline 00845 . & 309 & $\mathrm{M} 4 \mathrm{n}$ top $(\mathrm{M})$ \\
\hline \multirow[t]{2}{*}{00863.} & 273 & Muderongia australis (P) FO \\
\hline & 261 & Phoberocysta neocomica LO (P) \\
\hline 00866. & 189 & Tubodiscus verenae $\mathrm{LO}(\mathrm{N})$ \\
\hline 00867. & 215 & Tegumentum tripes $(\mathrm{N})$ LO \\
\hline \multirow[t]{3}{*}{00873.} & 155 & Cruciellipsis cuvillieri LO (N) \\
\hline & 96 & Dorothia praehauteriviana LO (BF) \\
\hline & 94 & Gavelinella bettenstaedti $\mathrm{P}$ (BF) \\
\hline \multirow[t]{3}{*}{00882.} & 76 & Lenticulina ouachensis LO (BF) \\
\hline & 92 & Paalzowella feifeli LO (BF) \\
\hline & 93 & Epistomina caracolla $\mathrm{P}$ (BF) \\
\hline
\end{tabular}

11. ODP Leg 123, Hole 765C, Eastern Indian Ocean.

\begin{tabular}{lrl} 
Depth & Number & \multicolumn{1}{c}{ Fossil Name } \\
\hline 00883. & 185 & Rucinolithus wisei LO (N) \\
00886. & 213 & Tegumentum striatum (N) LO \\
00891. & 68 & Haplophragmium inconstans LO (BF) \\
00892. & 188 & Tubodiscus verenae FO (N) \\
& 212 & Tegumentum striatum (N) FO \\
& 214 & Tegumentum tripes (N) FO \\
00893. & 184 & Rucinolithus wisei FO (N) \\
& 211 & Crucibiscutum salebrosum (N) FO \\
& 154 & Cruciellipsis cuvillieri FO (N) \\
00901. & 55 & Dorothia praehauteriviana FO (BF) \\
00903. & 275 & Verneuilinoides neocomiensis LO (BF) \\
00904. & 276 & Egmontodinium torynum (P) P \\
00905. & 274 & Batioladinium reticulatum (P) P \\
00908. & 88 & Trochammina quinqueloba LO (BF) \\
00910. & 91 & Pseudoreophax cisovnicensis FO (BF) \\
00922. & 95 & Hormosina cf. crassa FO (BF) \\
00926 & 90 & Verneuilinoides neocomiensis FO (BF) \\
00928 & 210 & Cyclagelosphaera deflandrei (N) FO \\
& &
\end{tabular}

12. ODP Leg 123, Site 766, Eastern Indian Ocean.

Depth Number Fossil Name

\begin{tabular}{lrl}
\hline 00253. & 305 & M2n top (M) \\
00259. & 307 & M3r top (M) \\
00272. & 155 & Cruciellipsis cuvillieri LO (N) \\
00290. & 97 & Gavelinella barremiana $\mathrm{FO}(\mathrm{BF})$ \\
00292. & 72 & Lenticulina crepidularis LO (BF) \\
00346. & 317 & M8n top (M) \\
00374. & 319 & M9n top (N) \\
00392. & 98 & Conorboides hofkeri FO (BF) \\
00400. & 321 & M10n top (M) \\
00422. & 76 & Lenticulina ouachensis LO (BF) \\
00425. & 323 & M10Nn top (M) \\
00434. & 213 & Tegumentum striatum (N) LO \\
00441. & 325 & M11n top (M) \\
00443. & 189 & Tubodiscus verenae LO (N) \\
00471. & 214 & Tegumentum tripes (N) FO \\
& 188 & Tubodiscus verenae FO (N) \\
& 210 & Cyclagelosphaera deflandrei (N) FO \\
& 212 & Tegumentum striatum (N) FO \\
& 211 & Crucibiscutum salebrosum (N) FO \\
& 154 & Cruciellipsis cuvillieri FO (N) \\
\end{tabular}

13. DSDP Leg 27, Site 261, Eastern Indian Ocean.

\begin{tabular}{lrl} 
Depth & Number & \multicolumn{1}{c}{ Fossil Name } \\
\hline 00363. & 301 & M0r top (M) \\
00366. & 303 & M1n top (M) \\
00381. & 305 & M2n top (M) \\
00404. & 307 & M3r top (M) \\
00438. & 309 & M4n top (M) \\
00447. & 155 & Cruciellipsis cuvillieri LO (N) \\
00487. & 188 & Tubodiscus verenae FO (N) \\
00494. & 68 & Haplophragmium inconstans LO (BF) \\
& 89 & Verneuilinoides neocomiensis LO (BF) \\
00506. & 206 & Reinharditites fenestratus FO (N) \\
00507. & 154 & Cruciellipsis cuvillieri FO (N) \\
00525. & 88 & Trochammina quinqueloba LO (BF) \\
00532. & 208 & Speetonia colligata FO (N) \\
& 186 & Stephanolithion bigotii LO (N) \\
& 67 & Haplophragmium inconstans FO (BF) \\
00549. & 87 & Trochammina quinqueloba FO (BF) \\
& 90 & Verneuilinoides neocomiensis FO (BF) \\
& 78 & Lenticulina quenstedti LO (BF)
\end{tabular}

